Article

\title{
Biogeographic, Atmospheric, and Climatic Factors Influencing Tree Growth in Mediterranean Aleppo Pine Forests
}

\author{
J. Julio Camarero ${ }^{1, *(\mathbb{D}}$, Raúl Sánchez-Salguero ${ }^{1,2} \mathbb{D}$, Montserrat Ribas ${ }^{3}$, Ramzi Touchan ${ }^{4}$, \\ Laia Andreu-Hayles ${ }^{5}$, Isabel Dorado-Liñán ${ }^{6}$ (D), David M. Meko ${ }^{4}$ and Emilia Gutiérrez ${ }^{3}$ (D) \\ 1 Instituto Pirenaico de Ecología (IPE-CSIC), 50192 Zaragoza, Spain; rsanchez@upo.es \\ 2 Departamento de Sistemas Físicos, Químicos y Naturales, Universidad Pablo de Olavide, 41013 Sevilla, Spain \\ 3 Department of Evolutionary Biology, Ecology and Environmental Sciences, University of Barcelona, \\ 08028 Barcelona, Spain; jevilady@gmail.com (M.R.); emgutierrez@ub.edu (E.G.) \\ 4 Laboratory of Tree-Ring Research, University of Arizona, Tucson, AZ 85721-0045, USA; \\ rtouchan@ltrr.arizona.edu (R.T.); dmeko@ltrr.arizona.edu (D.M.M.) \\ 5 Tree-Ring Laboratory, Lamont-Doherty Earth Observatory of Columbia University, \\ Palisades, NY 10964, USA; lah@ldeo.columbia.edu \\ 6 Forest Genetics and Ecophysiology Research Group, Technical University of Madrid (UPM), 28040 Madrid, \\ Spain; isabel.dorado@upm.es \\ * Correspondence: jjcamarero@ipe.csic.es; Tel.: +34-976-363-222 (ext. 880041)
}

Received: 16 June 2020; Accepted: 2 July 2020; Published: 6 July 2020

check for updates

\begin{abstract}
There is a lack of knowledge on how tree species respond to climatic constraints like water shortages and related atmospheric patterns across broad spatial and temporal scales. These assessments are needed to project which populations will better tolerate or respond to global warming across the tree species distribution range. Warmer and drier conditions have been forecasted for the Mediterranean Basin, where Aleppo pine (Pinus halepensis Mill.) is the most widely distributed conifer in dry sites. This species shows plastic growth responses to climate, being particularly sensitive to drought. We evaluated how 32 Aleppo pine forests responded to climate during the second half of the 20th century by using dendrochronology. Climatic constraints of radial growth were inferred by fitting the Vaganov-Shashkin (VS-Lite) growth model to ring-width data from our Aleppo pine forest network. Our findings reported that Aleppo pine growth decreased and showed the highest common coherence among trees in dry, continental sites located in southeastern and eastern inland Spain and Algeria. In contrast, growth increased in wetter sites located in northeastern Spain. Overall, across the Aleppo pine network tree growth was enhanced by prior wet winters and cool and wet springs, whilst warm summers were associated with less growth. The relationships between site ring-width chronologies were higher in nearby forests. This explains why Aleppo pine growth was distinctly linked to indices of atmospheric circulation patterns depending on the geographical location of the forests. The western forests were more influenced by moisture and temperature conditions driven by the Western Mediterranean Oscillation (WeMO) and the Northern Atlantic Oscillation (NAO), the southern forests by the East Atlantic (EA) and the august NAO, while the Balearic, Tunisian and northeastern sites by the Arctic Oscillation (AO) and the Scandinavian pattern (SCA). The climatic constraints for Aleppo pine tree growth and its biogeographical variability were well captured by the VS-Lite model. The model performed better in dry and continental sites, showing strong growth coherence between trees and climatic limitations of growth. Further research using similar broad-scale approaches to climate-growth relationships in drought-prone regions deserves more attention.
\end{abstract}

Keywords: dendroecology; drought; Pinus halepensis; radial growth; VS-Lite model 


\section{Introduction}

The Mediterranean Basin is a climate-warming hotspot where aridification trends have intensified since the 1980s, and are negatively impacting forest productivity and radial growth of some tree species [1,2]. However, droughts do not impact tree populations of the same species in the same way, since there are geographical patterns in adaptation [3]. The Mediterranean Basin climate is characterized by a transition from dry and semi-arid conditions in southern and low-elevation sites towards more continental or temperate conditions in northern and high-elevation sites [4]. Regions with more continental conditions are usually drier than regions more influenced by sea convective storms (e.g., compare the Iberian and Italian peninsulas). Such geographical variability in aridity or continentality also influences growth responses to climate warming. In addition, regional rainfall regimes vary along a longitudinal gradient, with more winter-spring precipitation westwards and more autumn precipitation eastwards [5]. This humidity gradient has been associated to distinct forest productivity that has been described as an east-west tree growth dipole across the Mediterranean Basin related to several atmospheric patterns [6-8]. However, local factors also influence tree growth, and may decouple regional circulation patterns from site climate conditions as has been reported in eastern Mediterranean sites [9]. Therefore, we need better biogeographic characterizations of the forest responses to the Mediterranean climate at regional and local scales [8]. The analyses of climate-growth relationships across wide geographical and climatic gradients would help to determine the vulnerability of tree populations or provenances to warming-related drought impacts. Tree-ring networks composed by several sites of the same species provide a powerful tool to assess tree growth responses to climate change across space $[10,11]$.

The diversity in climate conditions and ecological settings across the Mediterranean Basin could favor growth plasticity in response to the climate of widespread tree species such as Aleppo pine (Pinus halepensis Mill.). Aleppo pine is one of the Mediterranean tree species that better tolerates summer drought [10-13]. To assess how plastic the response of Aleppo pine radial growth is to climate warming and water shortage, we need broad evaluations across its distribution range, explicitly considering climate-growth associations at different geographical scales, as well as also their connections to atmospheric circulation patterns. These analyses of climate-growth responses across a broad geographical region provide a spatial analogue to understand and forecast how Aleppo pine growth will respond to climate warming. In addition, establishing associations to large-scale atmospheric circulation patterns provides a better understanding on how regional climate impacts forest productivity [5]. The distinct geographical influence of the atmospheric patterns modulates different seasonal precipitation regimes in the Western and the Eastern regions of the Mediterranean Basin that explain the east-west tree growth dipole [6,8].

Tree growth responsiveness to climate across ample geographic and climatic gradients can be adequately characterized using process-based models of tree-ring formation [14,15], which allow quantifying climatic thresholds of radial growth [16]. These models are based on several parameters and used climate variables as input to simulate growth variability and can estimate temperature and soil moisture thresholds for ring formation and tree radial growth [17]. Furthermore, these growth models are based on intra-annual xylem development (xylogenesis), which is very plastic in Aleppo pine [18-25]. Studies on xylogenesis have demonstrated that cambial activity and growth slow down or may stop during warm-dry summers, and always stops during the dormant period in the cold winter.

Here we analyzed and characterized the biogeographic, atmospheric, and climatic factors influencing tree growth in Mediterranean Aleppo pine forests. The quantification of growth responses to climate and atmospheric patterns allows for assessing tree adaptation to climate conditions, and inferring the vulnerability of tree populations against climate warming. We expected that Aleppo pine will show a plastic growth response to growing-season moisture depending on site location, being constrained by distinct climatic conditions (e.g., cold winters) modulated by atmospheric circulation patterns. The Vaganov-Shashkin (VS-Lite) forward growth model [26] was used to infer the main climatic constraints of growth across the species distribution range. 


\section{Materials and Methods}

\subsection{Study Region and Tree Species}

This study includes Aleppo pine forests across the Mediterranean Basin (see Table 2 and Figure 1). Most of the sites are located in eastern Spain, where climate is mainly Mediterranean, characterized by summer drought and wet-cool conditions in spring and autumn. Nevertheless, in eastern Spain, the Mediterranean climate shows high variability, including continental (inland or in mountain areas) and mesic conditions near the coast. There are seasonal shifts from wetter autumn conditions eastwards to wetter winter-spring conditions westwards, depending on the influence of Mediterranean or Atlantic dynamics [27].

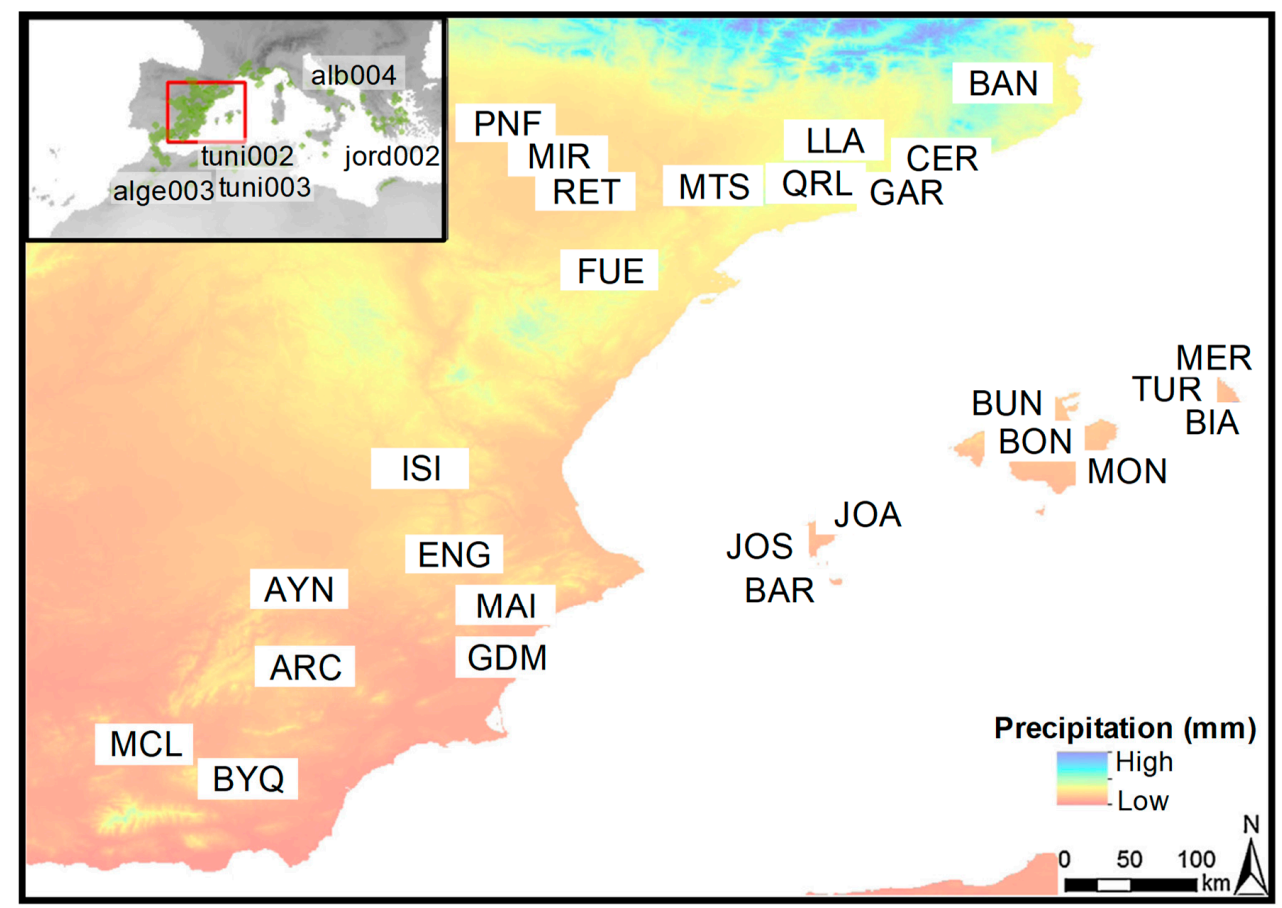

Figure 1. Map showing the location of the study sites (see sites' codes in Table 2). The larger map shows the locations of the forests in eastern Spain. The upper inset map shows the distribution of Aleppo pine in the Mediterranean Basin (green), the eastern study region (red square) and the approximate location of International Tree-Ring Data Bank (ITRDB) sites. The background color key of the map shows the precipitation of the driest quarter (period of three months).

The Aleppo pine (Pinus halepensis Mill.) natural forests and plantations cover ca. $30,000 \mathrm{~km}^{2}$ in the Mediterranean Basin, being more abundant in the western (mainly in eastern Spain, southeastern France, and northern Algeria) than in the eastern Mediterranean Basin [28]. This species dominates the Mediterranean's humid to arid lowlands (annual precipitation from 200 up to $1500 \mathrm{~mm}$ ranging from 0 to $1000 \mathrm{~m}$ a.s.l.), but it can be found above $2000 \mathrm{~m}$ a.s.l. in the Atlas Mountains with warm conditions (mean annual temperature $13-20^{\circ} \mathrm{C}$ ) [28]. It is more abundant in dry regions (350-700 mm annual precipitation), with a long dry period (3-7 months) encompassing summer, and often late spring and autumn. Aleppo pine is usually dominant on marly substrates with calcareous and shallow (depth $<60 \mathrm{~cm}$ ) soils [28,29]. Aleppo pine is considered a drought-avoider isohydric species with very efficient stomatal control over water loss through leaves [30]. This implies a rapid use of soil water when it is available, and when soil moisture is limited a fast stomata closure that reduces carbon uptake, increases water use efficiency and avoids hydraulic failure when soil moisture is limiting [31,32].

The species shows great phenotypic plasticity and also ecotype variability [33] across its natural range of distribution, with diverse changes in anatomical [34], physiological (e.g., [30,31]), 
and biochemical traits related to water use (e.g., lumen diameter, water use efficiency) and tolerance to wildfire (e.g., bark thickness, maturity age) [28]. Genetically, Aleppo pine populations are more distinct and diverse in the eastern Mediterranean Basin than in its western counterpart (Spain, NW Africa) [28].

\subsection{Climate Data and Climate Indices Representing Major Atmospheric Patterns}

In the case of sites located in Spain ( $n=27$ sites), we used the local climate database developed by Ribas [10] by compiling monthly climate data (mean temperature and total precipitation) from meteorological stations located near the study sites. For the rest of sites (five sites), we used the EuMedClim $1 \mathrm{~km}$-resolution database, and used climate data for the period 1950-2014 considering the Mediterranean Basin [35]. In both cases, we calculated the mean annual temperature (MAT) and total annual precipitation $(M A P)$. To determine the site dryness, we calculated the aridity index of De Martonne $(A I)$ for each site as

$$
A I=M A P /(M A T+10)
$$

The $A I$ describes a range of aridity: lower than 10 (arid climates), $10<A I<20$ (semi-arid climates), $20<A I<25$ (strictly Mediterranean conditions), and $A I>25$ (humid conditions) [36].

In the Mediterranean Basin, western countries (Spain, Morocco) are more exposed to the influence of the Northern Atlantic Oscillation (NAO) than their eastern counterparts [4]. The NAO is negatively correlated with winter precipitation over most of the western Mediterranean region, and affects climate and tree growth in countries like Spain [5] and Morocco [37], but also in Italy [38]. Besides the $\mathrm{NAO}$, other related patterns influence the Mediterranean climate, such as the Arctic Oscillation (AO) and the Scandinavian pattern (SCA), particularly over the central Mediterranean [4]. In the eastern Mediterranean, the East Atlantic (EA) pattern also affects climate, reflecting precipitation variability not explained by the NAO, and the El Niño Southern Oscillation (ENSO) influences winter precipitation in that region $[9,39]$. Despite the assumed stronger influence of the NAO on Iberian climate, spring and summer precipitation are also influenced by the ENSO in this region [40]. Finally, we considered the Western Mediterranean Oscillation index (WeMO), which represents autumn-to-winter rainfall patterns over northern and eastern Iberia [41]. Positive WeMO phases correspond to high pressures over Iberia, and therefore, low precipitation.

Climate indices (NAO, AO, SCA, EA, and ENSO) were downloaded from the Climate Explorer website [42], and the WeMO index was obtained from the Climatology Group website of the University of Barcelona [43].

\subsection{Tree-Ring Width Data}

Our study includes tree-ring width data for 482 trees located in 32 sites from two main sources. First, we used the full tree-ring network of Aleppo pine developed for eastern Spain, including the Balearic Islands [10] (Table 2). Second, we downloaded all of the tree-ring series for Aleppo pine from the International Tree-Ring Data Bank (ITRDB) webpage [44], which fulfilled two criteria: (i) populations located in the Mediterranean Basin, and (ii) the last ring of sampled trees was formed after 1998. In total, five ITRDB sites were obtained from Algeria, Tunisia, Albania, and Jordan (Table 2, Figure 1). For the 27 sites in Spain, cores were extracted from dominant trees taken at $1.3 \mathrm{~m}$ using Pressler increment borers. None of the selected sites had been affected by local disturbances like wildfires for the past 30 years. This is supported by the finding of old trees in sampled sites (Table 1), the unevenly-aged tree distributions, and the absence of fire scars and charcoal in the soil. In each site, we sampled 10 to 23 trees, resulting in an average of 15 trees and 30 cores sampled per site (Table 1). These wood samples were carefully sanded until rings were visible, and visual cross-dating was performed by annotating very narrow or very wide rings [45]. At least two radii per tree were dated, and ring widths were measured to the nearest $0.01 \mathrm{~mm}$ using either Lintab-TSAP (RinntechTM, Heidelberg, Germany) or Velmex measuring devices (Velmex TA, Bloomfield, NY, USA). 
Table 1. Tree-ring width and VS-Lite statistics for the study sites. Mean ring widths were calculated for the common period 1950-1999, except for jord002 (1971-1994). The EPS is the Expressed Population Signal, and the best-replicated period was defined by EPS $>0.85$. The MS is the mean sensitivity. The percent variance accounted for the first principal component (VP1), and the signal-to-noise ratio (SNR) measures the internal coherence shared by all the series within a site. Regarding the VS-Lite model parameters, two of them determine when growth will not occur ( $\mathrm{T}_{1}$ for temperature and $\mathrm{M}_{1}$ for soil moisture), and the other two determine when growth is not limited anymore by climate constraints ( $\mathrm{T}_{2}$ for temperature and $\mathrm{M}_{2}$ for soil moisture). The last column shows the correlation ( $r$ ) between observed and VS-Lite simulated ring-width indices.

\begin{tabular}{|c|c|c|c|c|c|c|c|c|c|c|c|}
\hline \multirow[b]{2}{*}{ Site } & \multicolumn{6}{|c|}{ Tree-Ring Width Data } & \multicolumn{5}{|c|}{ Statistics of the VS-Lite Model } \\
\hline & No. Trees/No. Cores & Mean Width \pm SD (mm) & Best-Replicated Period & MS & VP1 (\%) & SNR & $\mathrm{T}_{1}\left({ }^{\circ} \mathrm{C}\right)$ & $\mathrm{T}_{2}\left({ }^{\circ} \mathrm{C}\right)$ & $\mathrm{M}_{1}(v / v)$ & $\mathbf{M}_{2}(v / v)$ & $r$ \\
\hline ARC & $15 / 31$ & $0.42 \pm 0.39$ & 1889-2001 & 0.41 & 72.7 & 28.5 & 5.60 & 13.83 & 0.09 & 0.17 & 0.62 \\
\hline AYN & $15 / 30$ & $0.53 \pm 0.27$ & 1862-1999 & 0.29 & 53.9 & 14.6 & 5.11 & 13.03 & 0.09 & 0.30 & 0.63 \\
\hline BAR & $15 / 30$ & $1.43 \pm 0.72$ & 1873-2001 & 0.26 & 61.0 & 16.2 & 3.93 & 10.82 & 0.07 & 0.38 & 0.52 \\
\hline BIA & $12 / 24$ & $1.57 \pm 0.74$ & 1940-2001 & 0.27 & 61.8 & 13.9 & 3.91 & 15.77 & 0.06 & 0.46 & 0.67 \\
\hline $\mathrm{BON}$ & $13 / 26$ & $0.78 \pm 0.24$ & 1911-2003 & 0.37 & 52.6 & 8.6 & 7.58 & 11.85 & 0.00 & 0.13 & 0.12 \\
\hline BUN & $15 / 25$ & $1.27 \pm 0.32$ & 1864-2003 & 0.29 & 56.8 & 16.5 & 7.07 & 22.07 & 0.01 & 0.34 & 0.65 \\
\hline ENG & $14 / 28$ & $0.60 \pm 0.36$ & 1860-2000 & 0.49 & 62.3 & 17.2 & 7.35 & 21.71 & 0.01 & 0.28 & 0.46 \\
\hline FUE & $16 / 31$ & $0.91 \pm 0.40$ & 1907-1999 & 0.29 & 57.2 & 17.9 & 8.09 & 15.71 & 0.01 & 0.42 & 0.50 \\
\hline GAR & $22 / 43$ & $0.95 \pm 0.25$ & 1938-2003 & 0.28 & 55.1 & 20.7 & 3.94 & 22.03 & 0.07 & 0.44 & 0.65 \\
\hline GDM & $15 / 28$ & $0.73 \pm 0.38$ & 1915-2000 & 0.24 & 46.5 & 10.8 & 5.45 & 19.59 & 0.05 & 0.15 & 0.59 \\
\hline ISI & $15 / 30$ & $1.05 \pm 0.40$ & 1920-1999 & 0.32 & 62.5 & 19.0 & 7.34 & 11.19 & 0.08 & 0.40 & 0.74 \\
\hline JOA & $16 / 31$ & $1.60 \pm 0.77$ & 1915-2001 & 0.35 & 65.4 & 21.4 & 8.16 & 12.07 & 0.03 & 0.35 & 0.70 \\
\hline JOS & $15 / 28$ & $1.57 \pm 0.65$ & 1920-2001 & 0.36 & 68.2 & 22.6 & 8.26 & 13.49 & 0.01 & 0.36 & 0.72 \\
\hline LLA & $16 / 27$ & $1.70 \pm 0.52$ & 1949-1999 & 0.21 & 48.2 & 11.8 & 6.00 & 13.22 & 0.00 & 0.27 & 0.43 \\
\hline MON & $15 / 30$ & $1.57 \pm 0.60$ & 1909-2003 & 0.32 & 52.1 & 11.5 & 6.51 & 19.29 & 0.02 & 0.19 & 0.34 \\
\hline MTS & $15 / 30$ & $1.15 \pm 0.31$ & 1919-1999 & 0.24 & 48.8 & 10.2 & 8.45 & 13.29 & 0.03 & 0.34 & 0.60 \\
\hline PNF & $23 / 43$ & $0.74 \pm 0.34$ & 1860-2004 & 0.44 & 69.8 & 35.3 & 6.61 & 11.14 & 0.01 & 0.27 & 0.67 \\
\hline QRL & $15 / 30$ & $2.04 \pm 0.60$ & 1948-1999 & 0.17 & 48.0 & 11.8 & 5.84 & 11.34 & 0.01 & 0.14 & 0.16 \\
\hline RET & $12 / 43$ & $0.85 \pm 0.36$ & 1857-2004 & 0.39 & 70.2 & 26.0 & 8.07 & 12.07 & 0.02 & 0.25 & 0.76 \\
\hline TUR & $10 / 21$ & $1.53 \pm 0.67$ & 1909-2001 & 0.25 & 50.1 & 10.0 & 4.58 & 15.99 & 0.06 & 0.41 & 0.44 \\
\hline alge003 & $20 / 39$ & $0.99 \pm 0.70$ & 1887-2006 & 0.44 & 71.3 & 44.4 & 7.23 & 12.65 & 0.00 & 0.40 & 0.74 \\
\hline tuni002 & $11 / 19$ & $1.60 \pm 0.99$ & 1912-2001 & 0.37 & 55.8 & 8.8 & 4.35 & 13.82 & 0.06 & 0.44 & 0.70 \\
\hline tuni003 & $14 / 25$ & $1.35 \pm 0.81$ & 1933-2001 & 0.38 & 59.6 & 17.0 & 2.77 & 11.82 & 0.07 & 0.44 & 0.67 \\
\hline alb004 & $20 / 40$ & $3.99 \pm 1.81$ & 1968-2008 & 0.23 & 32.9 & 7.5 & 4.44 & 16.75 & 0.01 & 0.38 & 0.52 \\
\hline jord002 & $14 / 14$ & $1.92 \pm 1.16$ & 1940-1994 & 0.35 & 45.7 & 7.0 & 6.40 & 10.93 & 0.05 & 0.13 & 0.73 \\
\hline
\end{tabular}


Table 2. Characteristics of the Aleppo pine study sites. Variables' abbreviations: MAT, mean annual temperature; MAP, mean annual precipitation; AI, De Martonne aridity index. * ITRDB sites [2,46-48].

\begin{tabular}{|c|c|c|c|c|c|c|c|}
\hline Site (Country) & Code & Latitude $\mathbf{N}\left({ }^{\circ}\right)$ & Longitude $-\mathrm{W} /+\mathrm{E}\left({ }^{\circ}\right)$ & Elevation (m a.s.1) & MAT $\left({ }^{\circ} \mathrm{C}\right)$ & $\operatorname{MAP}(\mathrm{mm})$ & AI \\
\hline Sierra de Archivel (Spain) & ARC & 32.092 & -2.033 & 1086 & 13.6 & 361 & 15.3 \\
\hline Ayna Los Luisos (Spain) & AYN & 38.594 & -2.079 & 1000 & 14.5 & 466 & 19.0 \\
\hline Banyoles (Spain) & BAN & 42.107 & 2.739 & 260 & 14.8 & 804 & 32.4 \\
\hline Es Cap de Barbaria (Spain) & BAR & 38.657 & 1.077 & 80 & 18.8 & 364 & 12.6 \\
\hline Cala Biniancolla (Spain) & BIA & 39.816 & 4.261 & 50 & 16.9 & 601 & 22.3 \\
\hline Santuari de Bonany (Spain) & $\mathrm{BON}$ & 39.582 & 3.076 & 200 & 17.5 & 594 & 21.6 \\
\hline Comuna de Bunyola (Spain) & BUN & 39.808 & 2.705 & 500 & 17.4 & 937 & 34.2 \\
\hline Pinar de Bayarque (Spain) & BYQ & 37.313 & -2.465 & 1280 & 12.6 & 347 & 15.4 \\
\hline Sta. Maria de Cervelló (Spain) & CER & 41.397 & 1.958 & 300 & 13.1 & 664 & 28.7 \\
\hline Serra d'Enguera (Spain) & ENG & 38.857 & -0.897 & 800 & 16.1 & 562 & 21.5 \\
\hline Fuentespalda (Spain) & FUE & 40.825 & 0.083 & 850 & 12.8 & 639 & 28.0 \\
\hline P.N. del Garraf (Spain) & GAR & 41.341 & 1.844 & 300 & 13.2 & 673 & 29.0 \\
\hline Guardamar del Segura (Spain) & GDM & 38.092 & -0.649 & 10 & 17.7 & 293 & 10.6 \\
\hline Los Isidros (Spain) & ISI & 39.450 & -1.275 & 635 & 13.1 & 450 & 19.5 \\
\hline Cala Xarraca (Spain) & JOA & 39.099 & 1.511 & 175 & 17.9 & 462 & 16.6 \\
\hline Sa Talaia de St. Josep (Spain) & JOS & 38.909 & 1.256 & 360 & 17.8 & 412 & 14.8 \\
\hline Serra d'Ancosa (Spain) & LLA & 41.450 & 1.533 & 730 & 12.3 & 607 & 27.2 \\
\hline Serra de Maigmó (Spain) & MAI & 38.525 & -0.636 & 900 & 14.9 & 351 & 14.1 \\
\hline El Mencal (Spain) & MCL & 37.514 & -3.173 & 1150 & 14.3 & 357 & 14.7 \\
\hline Es Mercadal (Spain) & MER & 39.999 & 4.063 & 200 & 17.5 & 606 & 22.0 \\
\hline Miramón (Spain) & MIR & 41.615 & -0.331 & 500 & 14.7 & 376 & 15.2 \\
\hline P.N. de Mondragó (Spain) & MON & 39.035 & 3.191 & 60 & 16.4 & 439 & 16.6 \\
\hline Serra de Montsant (Spain) & MTS & 41.329 & 0.820 & 775 & 13.2 & 670 & 28.9 \\
\hline Vedado de Peñaflor (Spain) & PNF & 41.779 & -0.709 & 350 & 14.0 & 416 & 17.3 \\
\hline Querol (Spain) & QRL & 41.387 & 1.433 & 770 & 13.4 & 493 & 21.1 \\
\hline La Retuerta de Pina (Spain) & RET & 41.480 & -0.242 & 386 & 15.8 & 428 & 16.6 \\
\hline Cala Turqueta (Spain) & TUR & 39.938 & 3.916 & 63 & 17.5 & 585 & 21.3 \\
\hline Tobji * (Algeria) & alge003 & 34.600 & 3.117 & 1380 & 13.4 & 338 & 14.1 \\
\hline Dahllia * (Tunisia) & tuni002 & 36.233 & 8.433 & 950 & 18.0 & 434 & 15.5 \\
\hline Jebnoun * (Tunisia) & tuni003 & 35.510 & 9.180 & 800 & 17.3 & 222 & 8.1 \\
\hline Divjakë * (Albania) & alb004 & 41.000 & 19.483 & 3 & 15.9 & 1027 & 39.6 \\
\hline Dibeen * (Jordan) & jord002 & 32.140 & 35.490 & 800 & 16.6 & 350 & 13.2 \\
\hline
\end{tabular}




\subsection{Processing Tree-Ring Width and Climate Data}

The resulting tree-ring-width data were detrended and standardized by using the software ARSTAN v.44 [49]. This procedure allows for removing growth trends due to changes in tree size, age, and stand dynamics. Detrending was done by fitting a 67\% cubic smoothing spline with a 50\% cutoff frequency $[47,50]$. Then, the resulting detrended series were pre-whitened with low-order autoregressive models to remove growth persistence. Individual ring-width indices were combined into site mean series or tree-ring width chronologies using a bi-weight robust mean [51].

The statistics for each chronology were calculated over the common 1950-1999 period (except for jord002 (Dibeen, Jordan) that used the 1971-1994 period) and are listed in Table 1: mean ring width and its standard deviation (SD), and the mean sensitivity (MS) of standard ring-width indices. The MS measures the relative change in width between consecutive rings with higher values, indicating higher growth variability [51]. The percent variance accounted for the first principal component (VP1), and the signal-to-noise ratio (SNR) was also obtained to assess the internal coherence, i.e., the common variability between tree-ring series obtained for a particular site [52]. Higher VP1 and SNR values indicate a greater coherence or similarity among individual ring-width series of the same site. We used an expressed population signal (EPS) $\geq 0.85$ threshold to assess the adequacy of replication in the early years of the chronology [53].

To characterize climate-growth relationships, we calculated Pearson correlations between tree-ring width chronologies and monthly climate data (mean temperature, total precipitation) from the previous September to current October, following previous studies (e.g., [11]). In the case of atmospheric patterns, we correlated tree-ring width chronologies and monthly and seasonal values of the corresponding indices (NAO, AO, SCA, EA, ENSO, and WeMO).

\subsection{Statistical Analyses}

To quantify to which degree growth variability depended on site location, we calculated two correlation matrices of inter-site distances between site chronologies for the common period 1950-1999. Then we plotted correlations as a function of distance, which is a kind of spatial correlogram [54].

To summarize the common variability among residual chronologies, a principal component analysis (PCA) was calculated on the variance-covariance matrix of the chronologies. We retained the first three principal components (PC1, PC2, and PC3) because they had eigenvalues higher than 1. To assess the relationship between sites and chronology features, we used the Spearman correlation coefficient $\left(r_{s}\right)$ when the studied variables did not follow normal distributions. In the case of normal distributions, we used the Pearson correlation coefficient $(r)$.

\subsection{VS-Lite Growth Model}

We used the VS-Lite forward growth model (see [26,55]) to assess differences in climatic controls of tree growth among sites. Mean site series of ring-width indices (chronologies) were simulated as a function of monthly climate variables (mean temperatures, total precipitation), based on the principle of limiting factors affecting tree growth, by using a simplified version of the process-based VS (Vaganov-Shashkin) model [17]. The VS-Lite model uses a Bayesian framework to estimate growth responses to temperature $\left(\mathrm{gT}\right.$, in $\left.{ }^{\circ} \mathrm{C}\right)$ and soil moisture content $(\mathrm{gM}$, in $v / v)$ limitations by calibrating four parameters. Two parameters determine when growth will not occur $\left(T_{1}\right.$ for temperature and $M_{1}$ for soil moisture), and the two parameters determine when growth is not limited anymore by climate constraints ( $\mathrm{T}_{2}$ for temperature and $\mathrm{M}_{2}$ for soil moisture). The solar radiation is modeled by considering insolation (gE parameter) estimated by site latitude. We compared the observed and simulated chronologies for the common 1950-1999 period and calculated Pearson correlation coefficients among them. We evaluated the assumption of uniform priors for the growth function parameters (with independent and normally distributed errors for ring-width indices) by 10,000 iterations, using three parallel chains and a white Gaussian noise model error (cf. [55]). To estimate monthly soil moisture from temperature and total 
precipitation, the VS-lite model uses the empirical leaky bucket model of hydrology. The specific parameters (e.g., runoff, root depth, growing season length, etc.) were taken from a previous study using a similar but more detailed modeling framework for Aleppo pine [14]. Snow dynamics were not considered, since snowfall is rare and not abundant in most of the study sites.

\section{Results}

\subsection{Tree-Ring Statistics and Sites Features}

The mean ring width $( \pm \mathrm{SD})$ was $1.40 \pm 0.63 \mathrm{~mm}$, with a minimum of $0.42 \mathrm{~mm}$ and a maximum of $3.99 \mathrm{~mm}$, found in the dry ARC (Sierra de Archivel) and wet alb004 (Divjakë) sites, respectively (Tables 1 and 2). The longest (129-165-year) and well-replicated chronologies were developed for several Spanish stands: (AYN (Ayna Los Luisos), BAR (Es Cap de Barbaria), BUN (Comuna de Bunyola), ENG (Serra d'Enguera), MIR (Miramón), PNF (Vedado de Peñaflor), and RET (La Retuerta de Pina), and also for the Algerian alge003 (120 years) site (Table 1). The mean MS was 0.33, with a minimum of 0.17 and a maximum of 0.49 in the QRL (Querol) and ENG sites, respectively. The mean variance accounted for by the first principal component (VP1) and the SNR were $58.2 \%$ and $17.5 \%$, respectively. In several sites, the VP1 was close or above $70 \%$ of the variance (e.g., ARC, BYQ, PNF, RET, and alge003), indicating a high coherence and sensitivity to a common environmental factor. The SNR reached values above 30 in the BYQ, PNF, and alge003 sites.

The growth rate increased in response to higher annual precipitation $\left(r_{s}=0.52, p=0.002\right)$ and eastwards $\left(r_{s}=0.63, p=0.001\right)$ location, and decreased in longer series $\left(r_{s}=-0.68, p<0.001\right)$. However, these negative correlations could depend on tree age or the site series length of the best-replicated period. After removing the dependency between growth rates and series length by obtaining residuals from a linear regression between both variables, we found that these residuals were still positively related to site precipitation $\left(r_{s}=0.45, p=0.01\right)$. Sites with a higher growth rate also presented lower mean sensitivity $\left(r_{s}=-0.48, p=0.006\right)$ and a lower coherence among trees (VP1: $r_{s}=-0.43, p=0.014$; SNR: $\left.r_{s}=-0.40, p=0.023\right)$. Consequently, the mean sensitivity (MS) was positively correlated with the chronology coherence, measured by either VP1 or SNR (VP1: $r_{s}=0.61, p<0.001$; SNR: $r_{s}=0.52$, $p=0.002)$. This explains why both the MS and the VP1 decreased as climate conditions became more wet (annual precipitation, MS: $r_{s}=-0.47, p=0.007$; VP1: $r_{s}=-0.44, p=0.013 ; A I$ (aridity index) MS: $r_{s}=-0.40, p=0.025$; VP1: $\left.r_{s}=-0.41, p=0.019\right)$. Lastly, as elevation increased MS $\left(r_{s}=0.43\right.$, $p=0.015)$ and SNR also increased $\left(r_{s}=0.37, p=0.040\right)$.

\subsection{Inter-Site Distance and Common Growth Variability of Aleppo Pine Sites}

The coherence in growth variations among nearby but also distant sites was weak to moderate. For instance, two sites located in the southern Balearic Islands (Ibiza) and Tunisia, ca. $800 \mathrm{~km}$ apart, showed a significant common growth variability $(r=0.58, p<0.001)$ throughout the 20th century (Figure 2a). Maximum correlations between site chronologies reached values of up to 0.90 (Figure 2b). Positive correlations were mainly found with inter-site distances of up to 1500-2000 km, albeit most of them were clustered in distances up to $800-1000 \mathrm{~km}$.

In the variance-covariance matrix for all sites, PC1, PC2, and PC3 accounted for $29.6 \%, 11.2 \%$, and $10.0 \%$, respectively, of the growth variability (Figure 3). PC1 corresponded to a longitudinal gradient separating eastern sites (e.g., jord002, alb004) from western sites, including several Iberian sites and inland populations (e.g., MIR, ISI (Figures 4 and 5). In contrast, PC2 was moderately related to site latitude with northern (e.g., MIR, RET) and southern (e.g., tuni002, alge003) sites, having low and high scores along this axis, respectively (Figures 4 and 5). Lastly, high scores of the PC3 were found for sites located in the Balearic Islands, coastal northeastern Spain, and Tunisia (e.g., MER, BAR, tuni002; see Figure 4). 
(a)

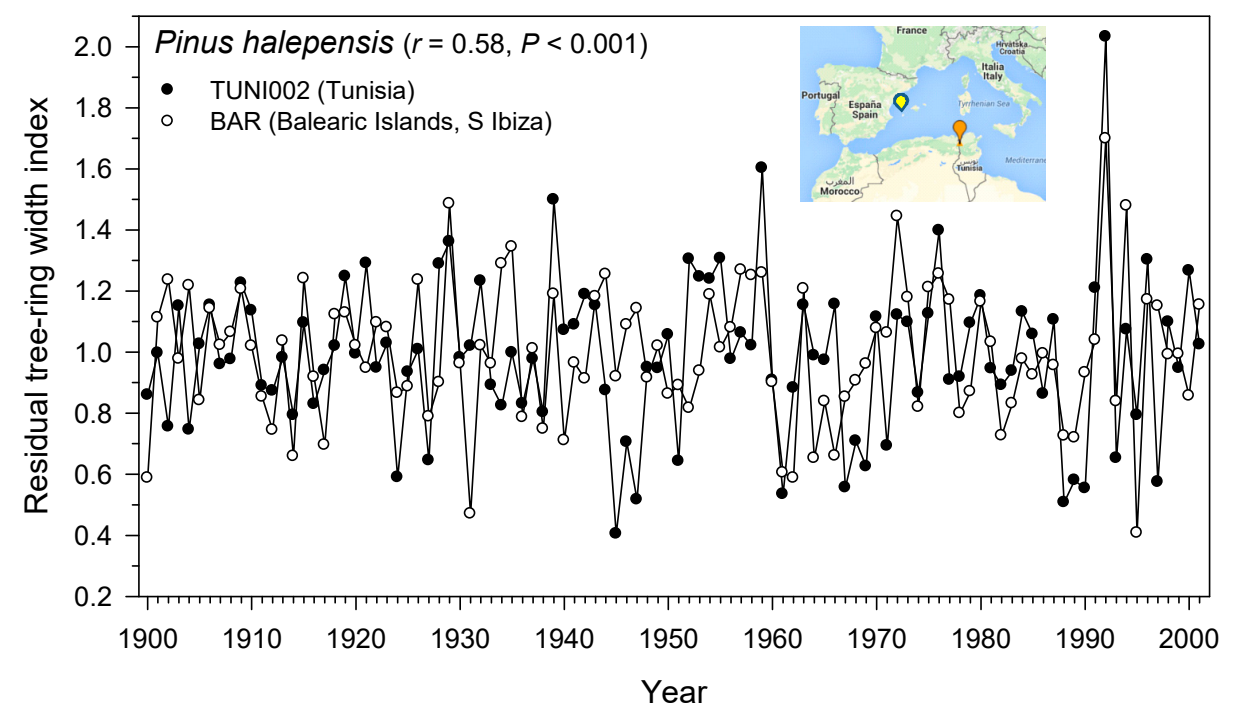

(b)

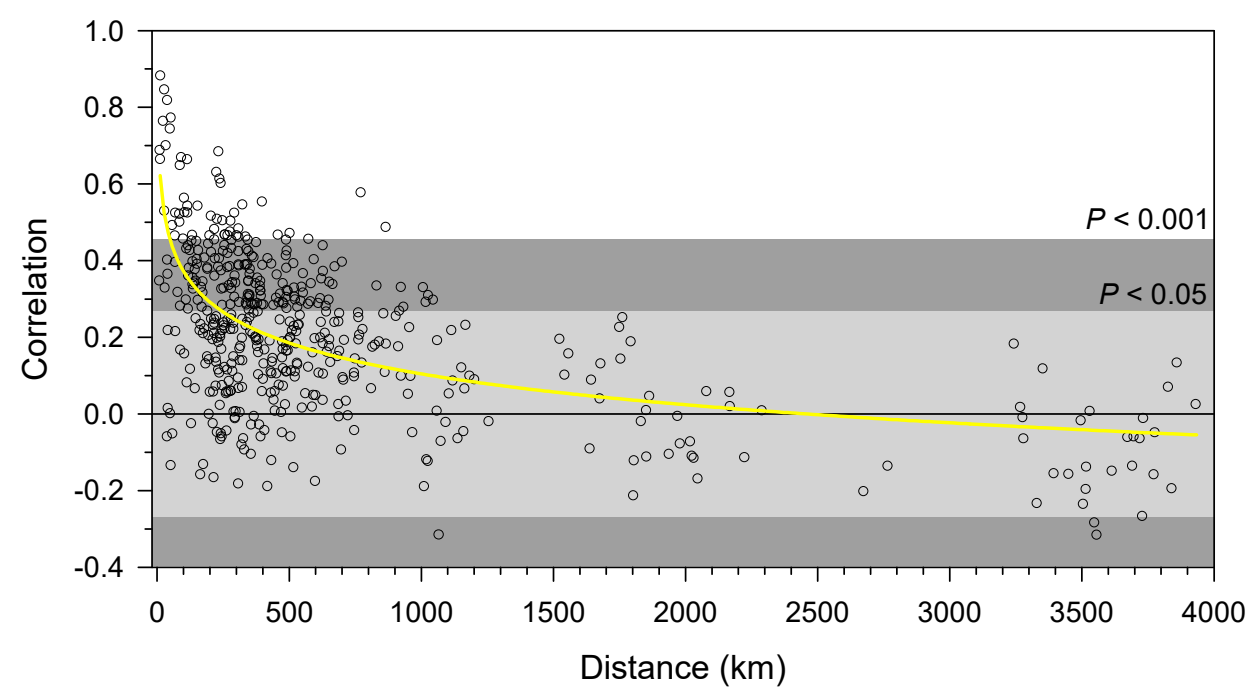

Figure 2. (a) Plot illustrating growth variability between two Aleppo pine sites situated in the southern Balearic Islands (Ibiza, site BAR) and northern Tunisia (tuni002, southernmost site). The residual chronologies were significantly correlated, despite the sites being located ca. $800 \mathrm{~km}$ apart. (b) Plot showing Pearson correlation coefficients between Mediterranean Aleppo pine chronologies decays as a function of distance between sites. The different grey intensities of the two boxes indicate the 0.05 and 0.001 significance levels for the analyzed 1950-1999 period. The yellow line shows a logarithmic function to describe the decay of correlations as a function of inter-site distance. 
(a)

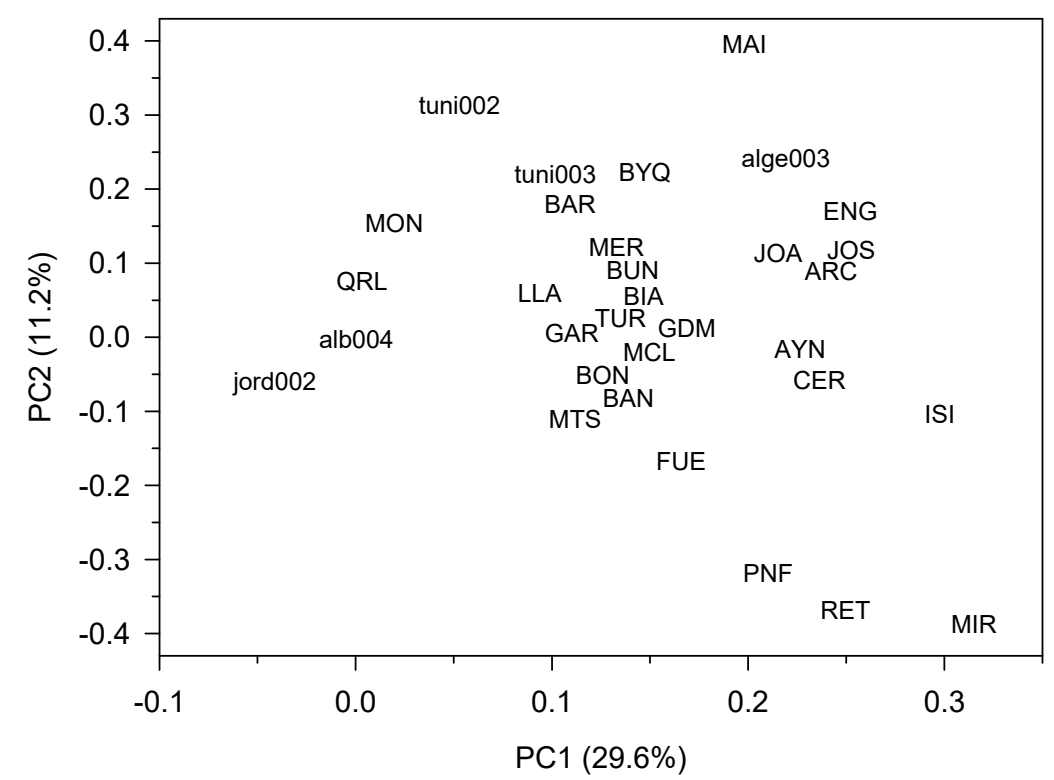

(b)

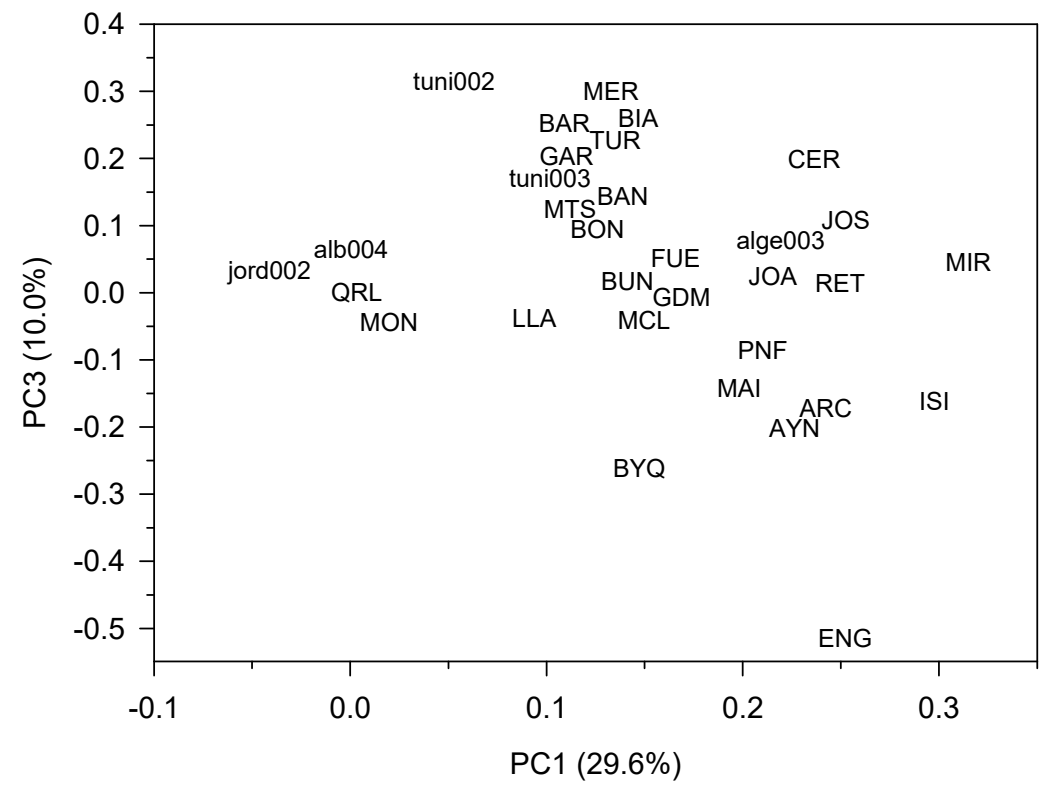

Figure 3. Scores of the Aleppo pine chronologies for the first three principal components (PC1, PC2, and PC3) of a principal component analysis (PCA) calculated on the variance-covariance matrix for the period 1950-1999: (a) PC1 versus PC2 and (b) PC1 versus PC3. Sites' codes are as in Table 2. 


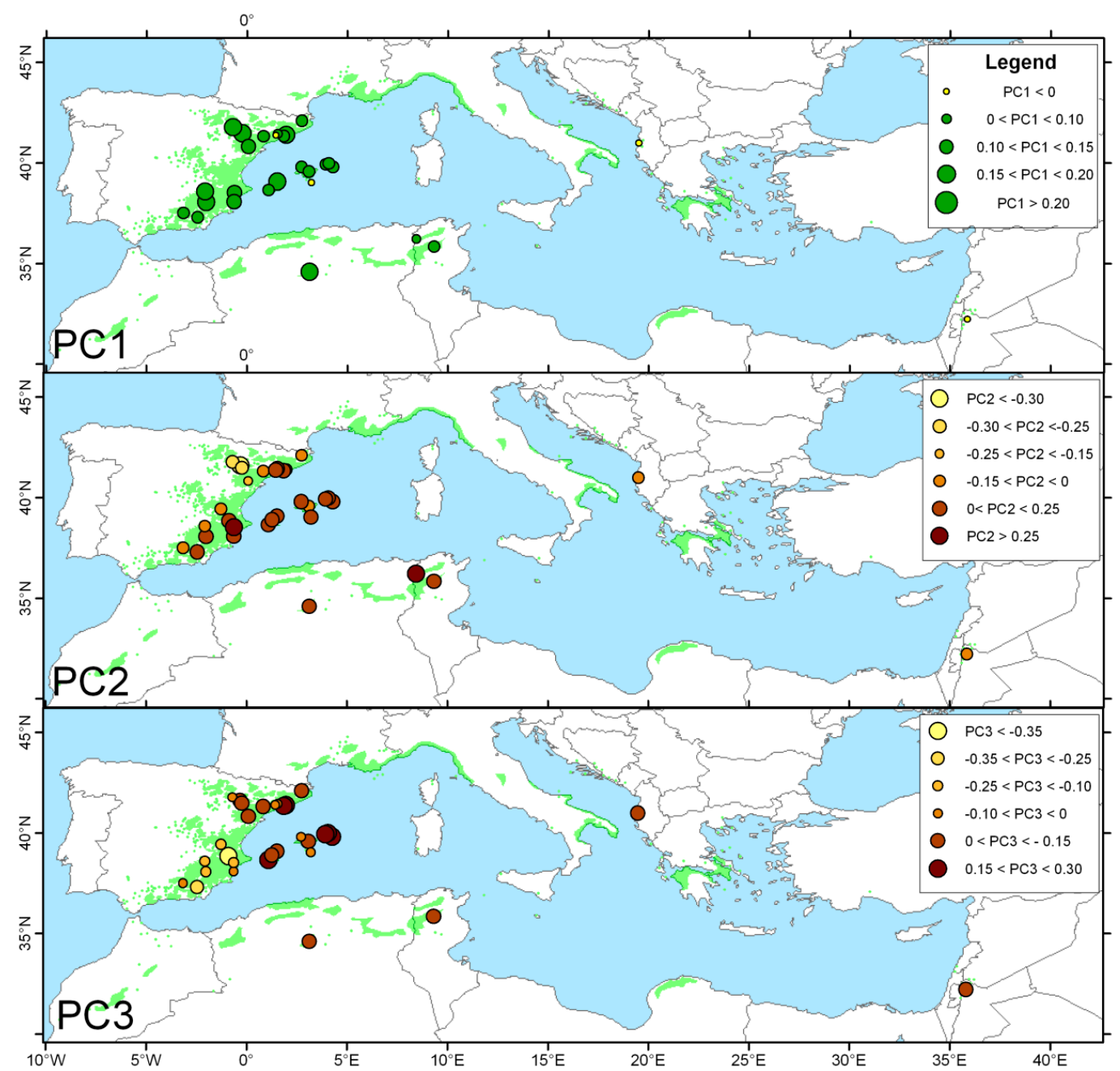

Figure 4. Map showing the scores of the first three principal components (PC1, PC2, and PC3) for the Aleppo pine chronologies distributed across the Mediterranean Basin. The green patches show the distribution of the species. 

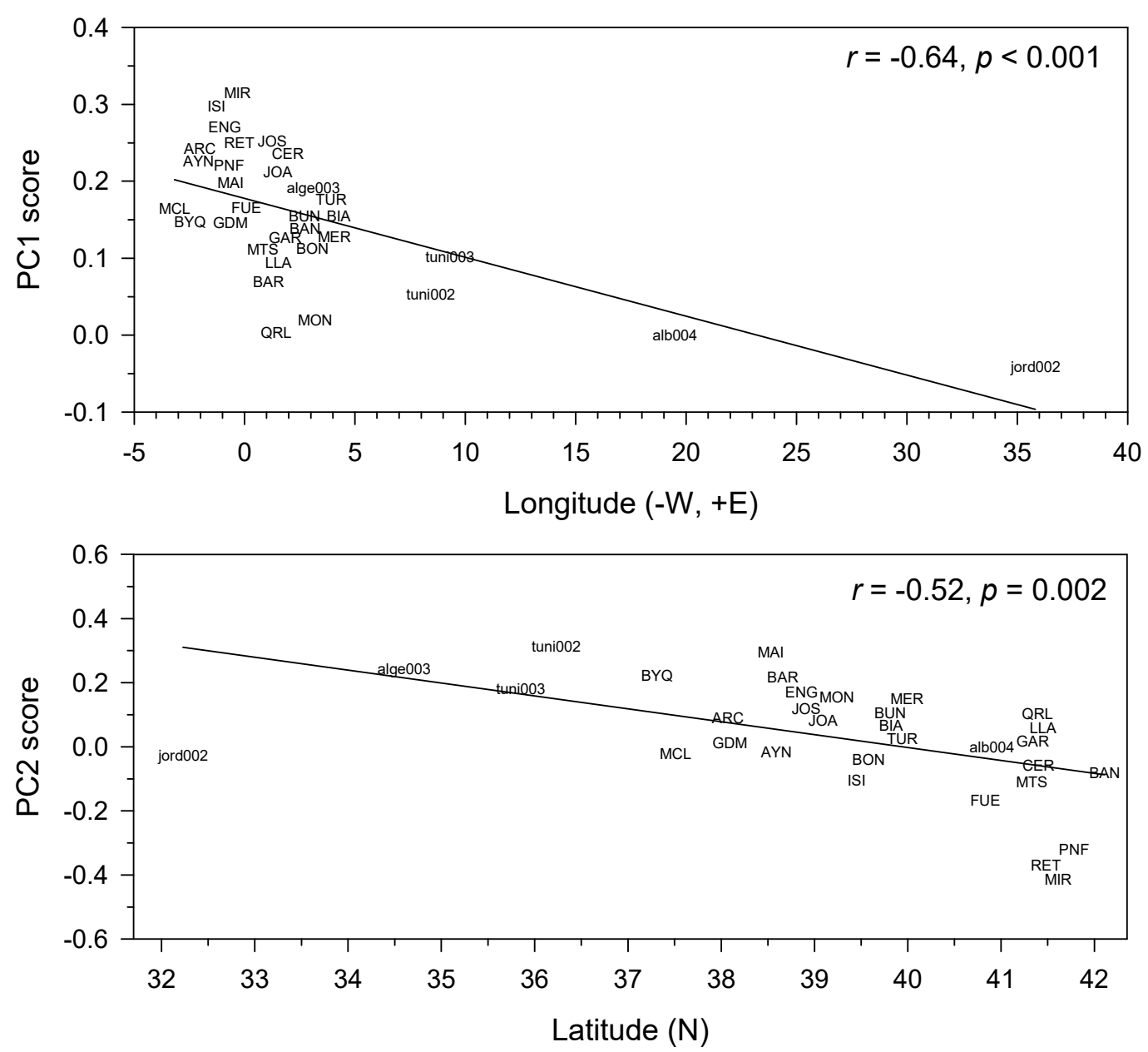

Figure 5. Relationships between location (longitude, latitude) and the scores of the first (PC1) and second (PC2) principal components scores of the analyzed network of Mediterranean Aleppo pine chronologies. The statistics show Pearson correlation coefficients $(r)$ and associated significance levels $(p)$. Sites' codes are as in Table 2. Note that the correlation between longitude and the PC1 scores was still significant if removing the two sites located eastwards of $15^{\circ} \mathrm{E}(r=-0.50, p=0.005)$. 


\subsection{Associations of Aleppo Pine Growth versus Climate Variables and Atmospheric Patterns}

Aleppo pine growth was positively associated to cool spring-summer (May to July) conditions (Figure 6a) and wet May conditions (Figure 6b). High precipitations in the prior winter, preceded by cool late autumn conditions, also enhanced growth (Figure $6 \mathrm{~b}$ ).

There were negative associations between the $\mathrm{PC} 1$ and $\mathrm{WeMO}$ and $\mathrm{NAO}$ indices of the previous winter (Figure 7). The PC2 showed a weak positive association $(r=0.39, p=0.004)$ with the August NAO index, and a negative association with the previous fall EA. The PC3 showed a positive correlation with the March SCA $(r=0.43, p=0.002)$, and a negative association with the March AO.

(a)

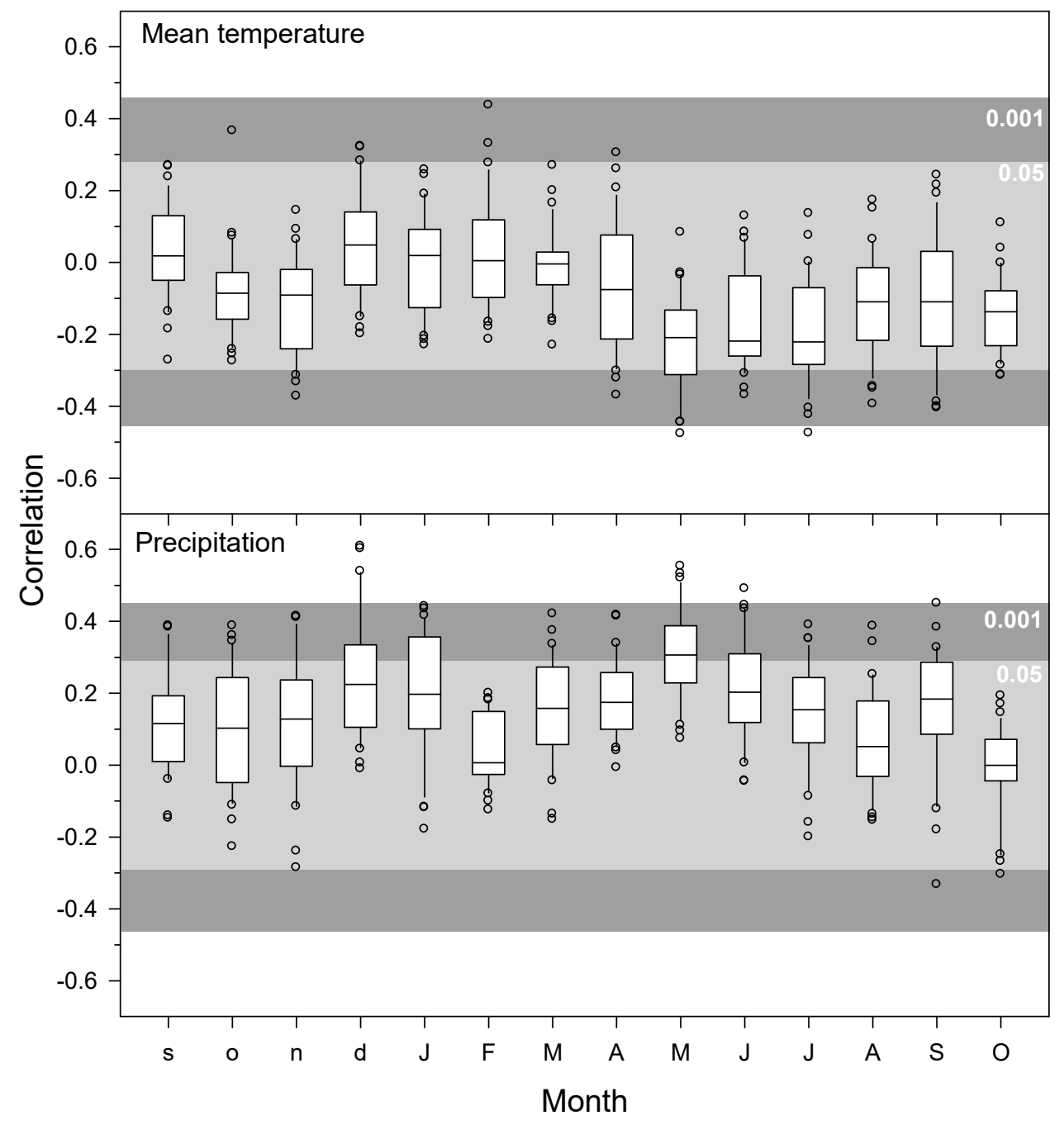

Figure 6. Climate-growth associations. Box plots of Pearson correlation coefficients obtained by relating monthly (a) mean temperature and (b) precipitation vs. residual Aleppo pine tree-ring width chronologies. 
(a)

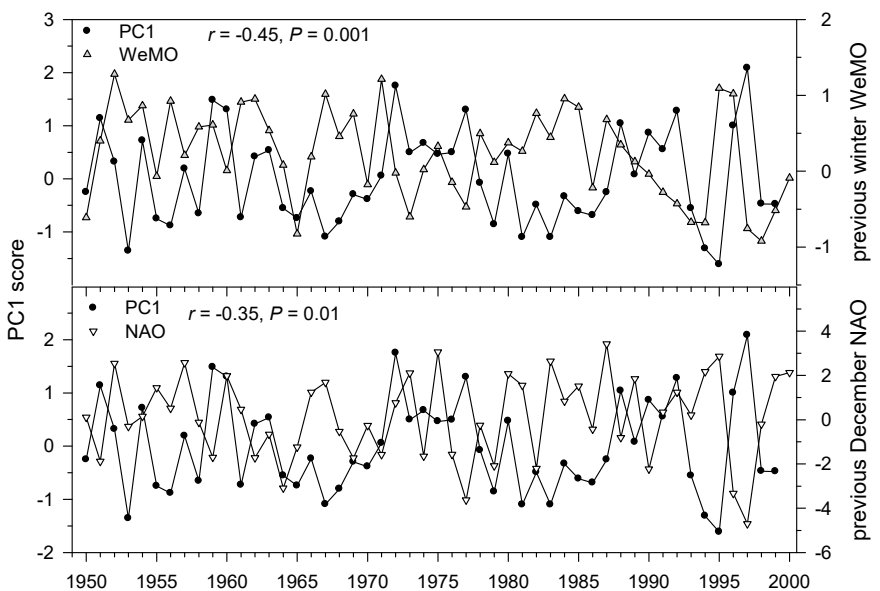

(b)

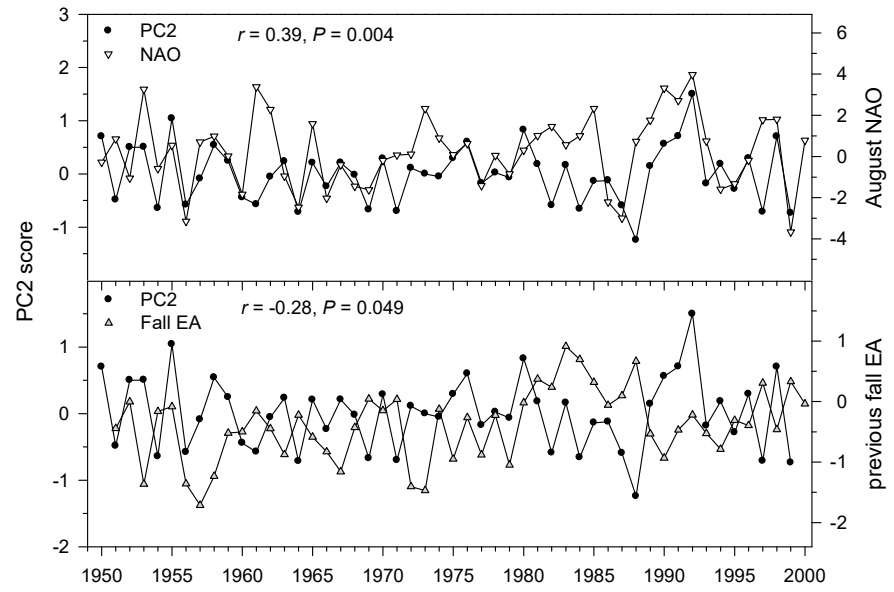

(c)

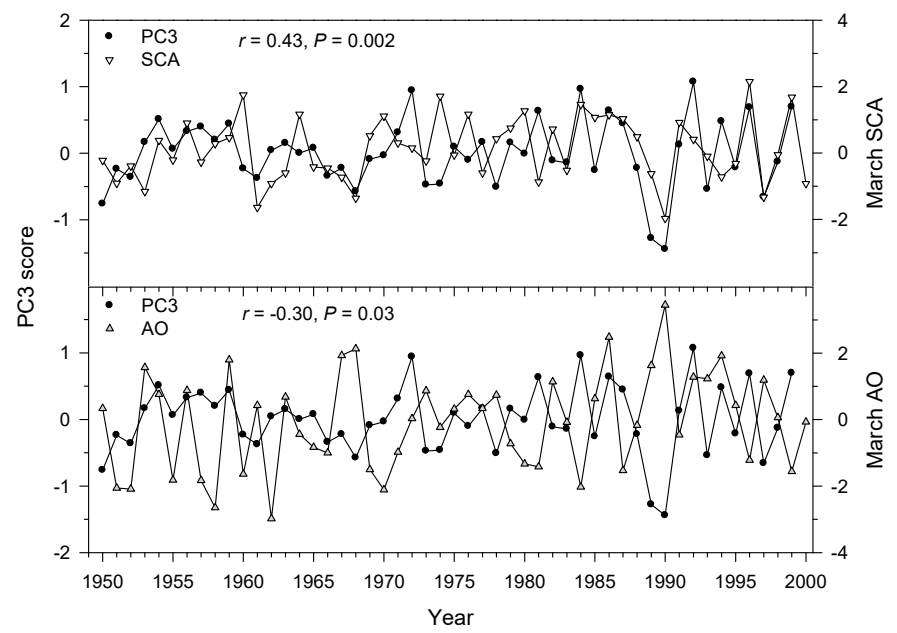

Figure 7. Major associations between (a) the first (PC1), (b) second (PC2), and (c) third (PC3) principal scores (filled black symbols) of a principal component analysis of Mediterranean Aleppo pine chronologies, and monthly or seasonal indices of different atmospheric circulation patterns (white and grey symbols). The statistics show Pearson correlations $(r)$ and associated significance levels $(p)$. Indices' and patterns' used are the Arctic Oscillation (AO), the East Atlantic pattern (EA), the NAO: Northern Atlantic Oscillation (NAO), the Scandinavian pattern (SCA) and the Western Mediterranean Oscillation index (WeMO). Correlations calculated with monthly or seasonal values of the indices or patterns of the year prior to tree-ring formation are indicated as "previous" in the $y$-axes. 


\subsection{Biogeographical Climate-Growth Associations Inferred from the VS-Lite Model}

We obtained positive correlations between observed and VS-Lite simulated chronologies (Table 1) being significant $(p<0.05)$ in all sites excepting BON (Santuari de Bonany) and QRL. These correlations reached maximum values between 0.74 and 0.76 , i.e., $55-58 \%$ of explained variability (sites ISI, MIR, RET, and alge003; see Table 1 ). The mean correlation was $0.57 \pm 0.16$, indicating that the model explained, on average, $32 \%$ of growth variability as a function of climate (Figure 8$)$. The mean $( \pm S D)$ fitted parameters were: $\mathrm{T}_{1}=6.0 \pm 1.9{ }^{\circ} \mathrm{C}, \mathrm{T}_{2}=14.4 \pm 3.7^{\circ} \mathrm{C}, \mathrm{M}_{1}=0.03 \pm 0.02 v / v$, and $\mathrm{M}_{2}=0.32$ $\pm 0.12 v / v$. The $\mathrm{M}_{1}$ and $\mathrm{T}_{1}$ parameters were negatively associated $\left(r_{s}=-0.48, p=0.006\right)$ showing that temperature and moisture are inversely associated. The $\mathrm{M}_{1}$ parameter was negatively related to site latitude $\left(r_{S}=-0.36, p=0.04\right.$; Figure 8$)$. The $\mathrm{M}_{2}$ parameter was positively related to site annual precipitation $\left(r_{S}=0.35, p=0.05\right)$. The correlations between the observed and fitted series of ring-width indices were positively related to SNR $\left(r_{s}=0.41, p=0.019\right)$, indicating than in sites where the VS-Lite model fit was robust, the chronology coherence was also high.

(a)

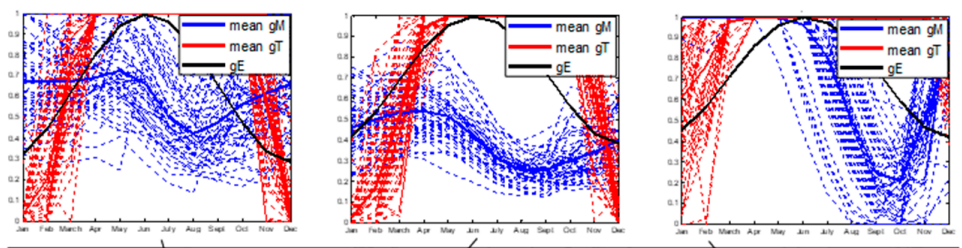

(b)

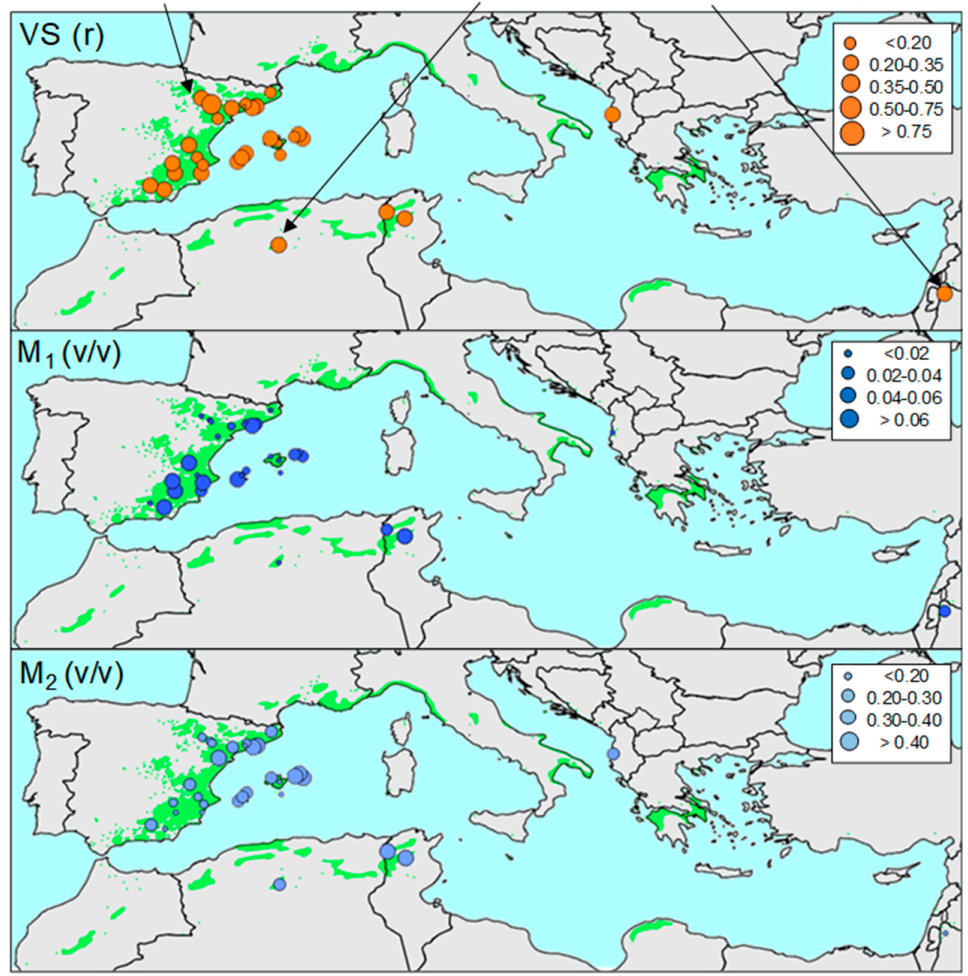

Figure 8. Parameters and statistics of the VS-Lite growth model applied to the Mediterranean Aleppo pine network. The correlation map ((a), VS $(r)$ ) shows the correlation between observed and simulated ring-width chronologies. The maps show the species distribution area (green patches) and VS-Lite parameters, indicating when growth will not occur because of moisture limitations $\left((\mathbf{b}), \mathrm{M}_{1}\right)$ and when growth is not any more limited by moisture $\left.((\mathbf{c})), \mathrm{M}_{2}\right)$. The three upper plots show fits in three sites (PNF, tuni003, jord002; see sites' codes in Table 2), displaying moisture (gM, blue lines) and temperature (gT, red lines) limitations for particular years and during the growing season ( $x$-axis). The black line (gE) shows the monthly insolation. 


\section{Discussion}

As in previous studies developed across the Mediterranean Basin, we found that Aleppo pine growth is very sensitive to soil water availability during spring and previous winter [2,9-13,46-48,56-62]. Our results also agree with the well-known period of highest growth rates for this species in early spring, dormant periods in summer and winter [18,20-23,62-65], and a secondary peak in autumn not always present $[24,25]$. Such bimodal behavior with growth peaks in spring and autumn is well-coupled to the Mediterranean climate with mild and wet conditions during these two seasons. The dormant periods agree with dry and cold constraining conditions in summer and winter, respectively, the latter being more marked in continental inland sites [66]. This phenological pattern can be explained because of higher carbon uptake through photosynthesis in late winter and early spring, which occur when soil moisture is high and vapor pressure deficit is low [67]. In summer and autumn, formed needles fix carbon and allow for storing carbohydrates for latewood production and for earlywood production in the following year, which explains why reduced growth is not related to low levels of non-structural carbohydrates $[68,69]$. In any case, the bimodal cambium phenology seems to be very plastic in Aleppo pine, and is controlled by site climate conditions, as indicated by empirical $[10,13,24]$ and modeling approaches [14]. It is foreseeable to have a more pronounced tree growth bimodality in mild coastal sites, where the growing season is much longer than in continental inland sites, where the growing season is shorter limited by summer drought and winter coldness [25].

In high-elevation conifer forest areas across the Alps, tree-ring width data showed strong correlations up to a mean distance of $374 \mathrm{~km}$, with tree species depending more on precipitation showing agreement within the smallest distances $(200-254 \mathrm{~km})$, and others more dependent on temperature showing broad coherence at larger scales (470-600 km) [54]. Results from our Aleppo pine network suggest growth agreement among forests up to distances of $1500-2000 \mathrm{~km}$, albeit most positive correlations were clustered about $800-1000 \mathrm{~km}$. This could be associated to the unbalanced site distribution towards the eastern coast of the Iberian Peninsula, where the main distribution area of this tree species is found [8]. These spatial patterns and elevation-grouped growth responses to climate (cf. [70]) should be considered when using tree-ring data of Aleppo pine as moisture proxies.

Regarding the links between growth variability and atmospheric patterns, the associations of the Aleppo pine tree-ring width network PC1 with the winter NAO and WeMO can be explained because cool-wet conditions in the prior winter benefitted growth, particularly in northeastern inland Spain [10-12,60]. The WeMO association with Aleppo pine growth has been found before [10], and highlights the relevance of this circulation pattern over winter moisture variability in the western Mediterranean Basin. In the case of the PC2, cool conditions in the previous autumn linked to the EA pattern could enhance the growth of stands located in southeastern Spain and Tunisia. The correlation between the PC2 and the August NAO could be explained by cool summer conditions, although the NAO mainly influences the spring and winter Iberian climate $[5,40]$. The relationships between the PC3 and March atmospheric patterns of the SCA and AO can be due to wetter conditions in early spring favoring the growth of coastal warm Aleppo pine populations, which probably show an early cambial reactivation [23]. Nonetheless, it must be considered that PC2 and PC3 only accounted for $21 \%$ of the growth variability in our study tree-ring network.

The correlations found between climate variables and tree-ring statistics were significant, but their values indicated moderate-to-weak relationships. This suggests that local factors, such as microclimate, soil characteristics, or provenance type, also influence growth responses to climate and growth coherence at regional scales. Another caveat of this study is that most of the tree-ring chronologies were built in the late 1990s and early 2000s and thus the latest 20 years of growth are not represented. Mediterranean climate has rapidly changed during the 21st century [1,2], thus the presented series should be updated to achieve more robust conclusions on the vulnerability of Aleppo pine forests to current climate change.

Several growth models have suggested that the increase in atmospheric $\mathrm{CO}_{2}$ could make trees more efficient in drought-prone areas and increase productivity in Mediterranean Aleppo pine forests [71,72]. 
However, field data do not support this assumption and have demonstrated that drought stress reduces radial growth and probably forest productivity, despite rising water-use efficiency [73-75]. Our results using the VS-Lite model in the studied Aleppo pine tree-ring network agreed with this lack of higher productivity associated to the increase in atmospheric $\mathrm{CO}_{2}$ concentrations and demonstrated that climatic constraints are modulating a significant proportion of radial growth distinctly across the species distribution range. For instance, the minimum moisture threshold $\left(\mathrm{M}_{1}\right)$ increased in the dry, warm sites from southeastern Spain, whilst maximum moisture threshold $\left(\mathrm{M}_{2}\right)$ increased in the wetter, colder (more continental) sites from northeastern Spain and the northern Balearic Islands. These differences indicate a wide range of growth variability, which may be due to local plasticity [11,76], and is probably associated with shifts in tree-ring phenology [25] or ecotype variability mediated by genetically fixed traits [77]. Nevertheless, the VS-Lite model explained, on average, $32 \%$ of year-to-year growth variability as a function of climate variables, as also revealed by previous studies of conifers species (e.g., [14-16]).

Our modeling approach provides robust results in agreement with previous findings from field studies on Aleppo pine (e.g, $[12,14,24])$. Nevertheless, the low explained variance in several sites illustrates some limitations of our approach, which would be improved by including more detailed data on individual tree size and age, neighborhood competition, disturbance history (e.g., wildfires; see [78]), carbon allocation, and soil features (type, depth, texture, and stoniness). For instance, soil water dynamics determine actual drought stress, and it has been shown that Aleppo pine has a better performance in marl and chalk substrates than in limestone [29]. Recently, it was shown that higher surface rock cover and topsoil stoniness increased soil water concentration and reduced mortality in a semi-arid Aleppo pine forest [79]. In addition, experiments on Aleppo pine saplings reported that drought triggered a shift of carbon allocation from the stem to the roots, with a $60 \%$ reduction of xylem volume in the stem [32]. Therefore, future studies could consider these factors and combine tree-ring data with variables related to tree size, carbon allocation (e.g., the concentration of non-structural carbohydrates in stem and roots), and water-use efficiency (e.g., C and O isotope discrimination; see [74]) in order to better simulate growth for Aleppo pine forests.

Aleppo pine is resistant to water shortage, but pronounced drought stress causes xylem embolism, particularly in fine roots, and reduces its growth and cone production [32,80-82]. Several dieback and pulsed-mortality episodes have been described in Mediterranean Aleppo pine forests in response to dry spells, indicating that this species is vulnerable to drought [83-86]. Such loss in tree vigor has been linked to xylem embolism and observed in relatively open stands, albeit a high tree-to-tree competition for water can exacerbate drought vulnerability [87]. In this sense, our modeling and biogeographical framework could be used to identify the Aleppo pine populations, whose growth will be more negatively impacted by drier and warmer conditions in the prior, early, or late growing seasons. Our quantification of growth response to local climate and large-scale atmospheric patterns across a wide geographical gradient in the widespread Aleppo pine forests is crucial to reveal differences and adaptation of this species under the forecasted drier and warmer climate conditions in the Mediterranean Basin (cf. [16,76]).

\section{Conclusions}

To conclude, correlations between climate and growth variability were moderate in the studied Aleppo pine forests. Tree radial growth was constrained during the second half of the 20th century by dry-warm spring conditions and dry prior winter conditions. Stronger growth responses to climate were mostly found in dry and continental inland sites, where the growing season is shorter, than in mild, coastal sites. Tree growth decreased in dry, xeric sites and increased in wet, mesic sites. The climate-growth relationships were higher in nearby forests and growth variations of Aleppo pine forests were linked to major atmospheric circulation patterns, which modulate moisture and temperature variability over the Mediterranean Basin where the trees are located. The VS-Lite model explained more growth variability in dry, continental sites. We advocate for similar regional approaches 
in drought-prone areas, using tree-ring networks of several tree species and multiple populations of each species.

Author Contributions: Conceptualization, J.J.C. and R.S.-S.; methodology, R.S.-S., M.R. and J.C.C.; software, R.S.-S.; validation, J.J.C., R.S.-S., D.M.M. and the rest of authors; formal analysis, J.J.C., M.R. and R.S.-S.; data curation, M.R. and R.S.-S.; writing-original draft preparation, J.C.C., R.S.-S., L.A.-H., I.D.-L., E.G., and all co-authors; writing-review and editing, all authors; funding acquisition, R.T., E.G., and J.J.C. All authors have read and agreed to the published version of the manuscript.

Funding: This research was funded by Spanish Ministry of Science, Innovation, and Universities, grant number FORMAL (RTI2018-096884-B-C31) and LESENS (RTI2018-096884-B-C33). R. Sánchez-Salguero and J.J. Camarero were also supported by VULBOS project (UPO-1263216, FEDER Funds, Andalusia Regional Government, Consejería de Economía, Conocimiento, Empresas y Universidad 2014-2020). This study was designed during a visit to R. Sánchez-Salguero and J.J. Camarero to the Laboratory of Tree-Ring Research (Tucson), hosted by Prof. Touchan, whose research was funded by the U.S. National Science Foundation, Earth System History (Grant No. 0075956) and National Science Foundation (Grant AGS-Paleo Perspectives on Climate Change Program 1103314).

Acknowledgments: We thank Chris Baisan for his assistance during field work.

Conflicts of Interest: The authors declare no conflict of interest. The funders had no role in the design of the study; in the collection, analyses, or interpretation of data; in the writing of the manuscript, or in the decision to publish the results.

\section{References}

1. Giorgi, F.; Lionello, P. Climate change projections for the Mediterranean region. Glob. Planet. Chang. 2008, 63, 90-104. [CrossRef]

2. Touchan, R.; Anchukaitis, K.J.; Meko, D.M.; Attalah, S.; Baisan, C.; Aloui, A. Spatiotemporal drought variability in northwestern Africa over the last nine centuries. Clim. Dyn. 2011, 37, 237-252. [CrossRef]

3. Dorado-Liñán, I.; Piovesan, G.; Martínez Sancho, E.; Gea-Izquierdo, G.; Zang, C.; Cañellas, I.; Castagneri, D.; Di Filippo, A.; Gutiérrez, E.; Ewald, J.; et al. Geographical adaptation prevails over species-specific determinism in trees' vulnerability to climate change at Mediterranean rear-edge forests. Glob. Chang. Biol. 2019, 25, 1296-1314. [CrossRef] [PubMed]

4. Xoplaki, E. Climate Variability over the Mediterranean. Ph.D. Thesis, University of Bern, Bern, Switzerland, 2002.

5. Camarero, J.J. Direct and indirect effects of the North Atlantic Oscillation on tree growth and forest decline in northeastern Spain. In Hydrological, Socioeconomic and Ecological Impacts of the North Atlantic Oscillation in the Mediterranean Region; Advances in Global Change Research 46; Vicente-Serrano, S.M., Trigo, R.M., Eds.; Springer: Berlin/Heidelberg, Germany, 2011; pp. 129-152.

6. Seim, A.; Treydte, K.; Trouet, V.; Frank, D.; Fonti, P.; Tegel, W.; Panayotov, M.; Fernández-Donado, L.; Krusic, P.; Büntgen, U. Climate sensitivity of Mediterranean pine growth reveals distinct east-west dipole. Int. J. Clim. 2015, 35, 2503-2513. [CrossRef]

7. Dorado-Liñán, I.; Zorita, E.; Martínez-Sancho, E.; Gea-Izquierdo, G.; Di Filippo, A.; Gutiérrez, E.; Levanič, T.; Piovesan, G.; Vacchiano, G.; Zang, C.; et al. Large-scale atmospheric circulation enhances the Mediterranean East-West tree growth contrast at rear-edge deciduous forests. Agr. For. Meteorol. 2017, 239, 86-95. [CrossRef]

8. Sangüesa-Barreda, G.; Camarero, J.J.; Sánchez-Salguero, R.; Gutiérrez, E.; Linares, J.C.; Génova, M.; Ribas, M.; Tíscar, P.A.; López-Sáez, J.A. Droughts and climate warming desynchronize Black pine growth across the Mediterranean Basin. Sci. Total Environ. 2019, 697, 133989. [CrossRef] [PubMed]

9. Touchan, R.; Xoplaki, E.; Funkhouser, G.; Luterbacher, J.; Hughes, M.K.; Erkan, N.; Akkemik, U.; Stephan, J. Reconstructions of spring/summer precipitation for the Eastern Mediterranean from tree-ring widths and its connection to large-scale atmospheric circulation. Clim. Dyn. 2005, 25, 75-98. [CrossRef]

10. Ribas, M. Dendroecología de Pinus Halepensis Mill. en el este de la Península Ibérica e islas Baleares: Sensibilidad y Grado de Adaptación a las Condicionesclimáticas. Ph.D. Thesis, Universitat de Barcelona, Barcelona, Spain, 2006.

11. De Luis, M.; Čufar, K.; Di Filippo, A.; Novak, K.; Papadopoulos, A.; Piovesan, G.; Rathgeber, C.B.; Raventós, J.; Saz, M.A.; Smith, K.T. Plasticity in dendroclimatic response across the distribution range of Aleppo pine (Pinus halepensis). PLoS ONE 2013, 8, e83550. [CrossRef] [PubMed] 
12. Gazol, A.; Ribas, M.; Gutiérrez, E.; Camarero, J.J. Aleppo pine forests from across Spain show drought-induced growth decline and partial recovery. Agr. For. Meteorol. 2017, 232, 186-194. [CrossRef]

13. Del Río, M.; Rodríguez-Alonso, J.; Bravo-Oviedo, A.; Ruíz-Peinado, R.; Cañellas, I.; Gutiérrez, E. Aleppo pine vulnerability to climate stress is independent of site productivity of forest stands in southeastern Spain. Trees 2014, 28, 1209-1224. [CrossRef]

14. Touchan, R.; Shishov, V.V.; Meko, D.M.; Nouiri, I.; Grachev, A. Process based model sheds light on climate sensitivity of Mediterranean tree-ring width. Biogeosciences 2012, 9, 965-972. [CrossRef]

15. Sánchez-Salguero, R.; Camarero, J.J.; Gutiérrez, E.; González Rouco, F.; Gazol, A.; Sangüesa-Barreda, G.; Andreu-Hayles, L.; Linares, J.C.; Seftigen, K. Assessing forest vulnerability to climate warming using a process-based model of tree growth: Bad prospects for rear-edges. Glob. Chang. Biol. 2017, 23, 2705-2719. [CrossRef]

16. Sánchez-Salguero, R.; Camarero, J.J.; Rozas, V.; Génova, M.; Olano, J.M.; Arzac, A.; Gazol, A.; Caminero, L.; Tejedor, E.; de Luis, M.; et al. Resist, recover or both? Growth plasticity in response to drought is geographically structured and linked to intra-specific variability in Pinus pinaster. J. Biogeogr. 2018, 45, 1126-1139.

17. Vaganov, E.A.; Hughes, M.K.; Shashkin, A. Growth Dynamics of Conifer Tree Rings: Images of Past and Future Environments; Springer: Berlin/Heidelberg, Germany, 2006.

18. Gindel, I. Cambial activity as a function of the intensity of transpiration in Pinus halepensis Mill. Proc. XVI IUFRO Congr. München 1967, 4, 188-206.

19. Serre-Bachet, F. Les rapports de la croissance et du climat chez le pin d'Alep. Acta Oecol./Oecol. Plant. 1976, 11, 143-171.

20. Liphschitz, N.; Lev-Yadun, S.; Rosen, E.; Waisel, Y. The annual rhythm of activity of the lateral meristems (cambium and phellogen) in Pinus halepensis Mill. and Pinus pinea L. IAWA Bull. 1984, 5, 263-274. [CrossRef]

21. Lev-Yadun, S. Wood Structure and the Ecology of Annual Growth Ring Formation in Pinus halepensis and P. brutia. In Ecology, Biogeography and Management of Pinus halepensis and P. brutia Forest Ecosystems in the Mediterranean Basin; Ne'eman, G., Trabaud, L., Eds.; Backhuys Publishers: Leiden, The Netherlands, 2000; pp. 67-78.

22. Nicault, A.; Rathgeber, C.; Tessier, L.; Thomas, A. Observations sur la mise en place du cerne chez le pin d'Alep (Pinus halepensis Mill.): Confrontation entre les mesures de croissance radiale, de densité et les facteurs climatiques. Ann. For. Sci. 2001, 58, 769-784. [CrossRef]

23. De Luis, M.; Gričar, J.; Čufar, K.; Raventós, R. Seasonal dynamics of wood formation in Pinus halepensis from dry and semi-arid ecosystems in Spain. IAWA J. 2007, 28, 389-404. [CrossRef]

24. Camarero, J.J.; Olano, J.M.; Parras, A. Plastic bimodal xylogenesis in conifers from continental Mediterranean climates. New Phytol. 2010, 185, 471-480. [CrossRef]

25. Pacheco, A.; Camarero, J.J.; Ribas, M.; Gazol, A.; Gutiérrez, E.; Carrer, M. Disentangling the climate-driven bimodal growth pattern in coastal and continental Mediterranean pine stands. Sci. Total Environ. 2018, 615, 1518-1526. [CrossRef]

26. Tolwinski-Ward, S.E.; Evans, M.N.; Hughes, M.; Anchukaitis, K. An efficient forward model of the climate controls on interannual variation in tree-ring width. Clim. Dyn. 2011, 36, 2419-2439. [CrossRef]

27. Allué, J.L. Atlas Fitoclimático de España; INIA-MAPA: Madrid, Spain, 1990.

28. Quézel, P. Taxonomy and biogeography of Mediterranean pines (Pinus halepensis and P. brutia). In Ecology, Biogeography and Management of Pinus halepensis and P. brutia Forest Ecosystems in the Mediterranean Basin; Neeman, L., Trabaud, L., Eds.; Backhuys Publishers: Leiden, The Netherland, 2000; pp. 1-12.

29. Schiller, G. Significance of bedrock as a site factor for Aleppo pine. For. Ecol. Manag. 1982, 4, $213-223$. [CrossRef]

30. Baquedano, F.J.; Valladares, F.; Castillo, F.J. Phenotypic plasticity blurs ecotypic divergence in the response of Quercus coccifera and Pinus halepensis to water stress. Eur. J. For. Res. 2008, 127, 495-506. [CrossRef]

31. Ferrio, J.P.; Florit, A.; Vega, A.; Serrano, L.; Voltas, J. Isotopic signature of $13 \mathrm{C}$ and tree-ring width reflect different drought responses in Quercus ilex and Pinus halepensis. Oecologia 2003, 137, 512-518. [CrossRef] [PubMed]

32. Klein, T.; Cohen, S.; Yakir, D. Hydraulic adaptations underlying drought resistance of Pinus halepensis. Tree Physiol. 2011, 31, 637-648. [CrossRef] [PubMed] 
33. Voltas, J.; Shestakova, T.; Patsiou, T.; di Matteo, G.; Klein, T. Ecotypic variation and stability in growth performance of the thermophilic conifer Pinus halepensis across the Mediterranean basin. For. Ecol. Manag. 2018, 424, 205-215. [CrossRef]

34. Esteban, L.G.; Martin, J.A.; de Palacios, P.; Fernández, F.G.; López, R. Adaptive anatomy of Pinus halepensis trees from different Mediterranean environments in Spain. Trees 2010, 24, 19-30. [CrossRef]

35. Fréjaville, T.; Benito-Garzón, M. The EuMedClim database: Yearly climate data (1901-2014) of 1 km resolution grids for Europe and the Mediterranean Basin. Front. Ecol. Evol. 2018, 6, 31. [CrossRef]

36. Tuhkanen, S. Climatic parameters and indices in plant geography. Acta Phyogeogr. Suecica 1980, 67, 1-105.

37. Glueck, M.F.; Stockton, C.W. Reconstruction of the North Atlantic Oscillation, 1429-1983. Int. J. Climatol. 2001, 21, 1453. [CrossRef]

38. Piovesan, G.; Schirone, B. Winter North Atlantic oscillation effects on the tree rings of the Italian beech (Fagus sylvatica L.). Int. J. Biometeorol. 2000, 44, 121-127. [CrossRef] [PubMed]

39. Yakir, D.; Lev-Yadum, S.; Zangvil, A. El Niño and tree growth near Jerusalem over the last 20 years. Glob. Chang. Biol. 1996, 2, 101-105.

40. Rodó, X.; Baert, E.; Comin, F.A. Variations in seasonal rainfall in southern Europe during the present century: Relationships with the North Atlantic Oscillation and the El Niño Southern Oscillation. Clim. Dyn. 1997, 13, 275-284. [CrossRef]

41. Martín-Vide, J.; López-Bustins, J.A. The Western Mediterranean Oscillation and rainfall in the Iberian Peninsula. Int. J. Climatol. 2006, 26, 1455-1475. [CrossRef]

42. KNMI Climate Explorer. Available online: https://climexp.knmi.nl/ (accessed on 20 March 2020).

43. WeMO. Available online: http://www.ub.edu/gc/wemo/ (accessed on 20 March 2020).

44. ITRDB. Available online: https://www.ncdc.noaa.gov/data-access/paleoclimatology-data/datasets/tree-ring (accessed on 20 March 2020).

45. Yamaguchi, D.K. A simple method for cross-dating increment cores from living trees. Can. J. For. Res. 1990, 21, 414-416. [CrossRef]

46. Touchan, R.; Hughes, M. Dendrochronology in Jordan. J. Arid Environ. 1999, 42, 291-303. [CrossRef]

47. Touchan, R.; Anchukaitis, K.J.; Meko, D.M.; Attalah, S.; Baisan, C.; Aloui, A. Long term context for recent drought in northwestern Africa. Geophys. Res. Lett. 2008, 35, L13705. [CrossRef]

48. Toromani, E.; Pasho, E.; Alla, A.Q.; Mine, V.; Çollaku, N. Radial growth responses of Pinus halepensis Mill. and Pinus pinea L. forests to climate variability in Western Albania. Geochronometria 2015, 42, 91-99. [CrossRef]

49. Cook, E.R.; Krusic, P. A Tree-Ring Standardization Program Based on Detrending and Autoregressive Time Series Modeling, with Interactive Graphics; Tree-Ring Laboratory, Lamont Doherty Earth Observatory, Columbia University: New York, NY, USA, 2005.

50. Touchan, R.; Meko, D.M.; Aloui, A. Precipitation reconstruction for Northwestern Tunisia from tree rings. J. Arid Environ. 2008, 72, 1887-1896. [CrossRef]

51. Fritts, H.C. Tree-Rings and Climate; Academic Press: London, UK, 1976.

52. Briffa, K.R.; Jones, P.D. Basic Chronology Statistics and Assessment. In Methods of Dendrochronology: Applications in the Environmental Sciences; Kluwer Academic Publishers: Berlin, Germany, 1990; pp. 137-152.

53. Wigley, T.M.; Briffa, K.R.; Jones, P.D. On the average value of correlated time series, with applications in dendroclimatology and hydrometeorology. J. Clim. Appl. Meteorol. 1984, 23, 201-213. [CrossRef]

54. Rolland, C. Decreasing teleconnections with inter-site distance in monthly climatic data and tree-ring width networks in a mountainous Alpine area. Theor. Appl. Climatol. 2002, 71, 63-75. [CrossRef]

55. Tolwinski-Ward, S.E.; Anchukaitis, K.J.; Evans, M.N. Bayesian parameter estimation and interpretation for an intermediate model of tree-ring width. Clim. Past 2013, 9, 1481-1493. [CrossRef]

56. Touchan, R.; Anchukaitis, K.J.; Meko, D.M.; Kerchouche, D.; Slimani, S.; Ilmen, R.; Hasnaoui, F.; Guibal, F.; Camarero, J.J.; Sánchez-Salguero, R.; et al. Climate controls on tree growth in the Western Mediterranean. Holocene 2017, 27, 1429-1442. [CrossRef]

57. Novak, K.; De Luis, M.; Raventos, J.; Čufar, K. Climatic signals in tree-ring widths and wood structure of Pinus halepensis in contrasted environmental conditions. Trees 2013, 27, 927-936. [CrossRef]

58. Papadopoulos, A.; Serré-Bachet, F.; Tessier, L. Tree ring to climate relationships of Aleppo pine (Pinus halepensis Mill.) in Greece. Ecol. Mediterr. 2001, 27, 89-98. [CrossRef] 
59. Olivar, J.; Bogino, S.; Spiecker, H.; Bravo, F. Climate impact on growth dynamic and intra-annual density fluctuations in Aleppo Pine (Pinus halepensis) trees of different crown classes. Dendrochronologia 2012, 30, $35-47$. [CrossRef]

60. Pasho, E.; Camarero, J.J.; de Luis, M.; Vicente-Serrano, S.M. Spatial variability in large-scale and regional atmospheric drivers of Pinus halepensis growth in eastern Spain. Agr. For. Meteorol. 2011, 151, 1106-1119. [CrossRef]

61. Pasho, E.; Camarero, J.J.; Vicente-Serrano, S.M. Climatic impacts and drought control of radial growth and seasonal wood formation in Pinus halepensis. Trees 2012, 26, 1875-1886. [CrossRef]

62. Choury, Z.; Shestakova, T.A.; Himrane, H.; Touchan, R.; Kerchouche, D.; Camarero, J.J.; Voltas, J. Quarantining the Sahara desert: Growth and water-use efficiency of Aleppo pine in the Algerian Green Barrier. Eur. J. For. Res. 2017, 136, 139-152. [CrossRef]

63. Oppenheimer, H.R. Cambial wood production in stems of Pinus halepensis. Palest. J. Bot. 1945, 5, $22-51$.

64. Attolini, M.R.; Calvani, F.; Galli, M.; Nanni, T.; Ruggiero, L.; Schaer, E.; Zuanni, F. The relationship between climatic variables and wood structure in Pinus halepensis Mill. Theor. Appl. Climatol. 1990, 41, 121-127. [CrossRef]

65. Serre-Bachet, F. Les enseignements écologiques de la variation de l'épaisseur du cerne chez le pin d'Alep. Forêt Méditerranéenne 1992, 8, 171-176.

66. Mitrakos, K. A theory for Mediterranean plant life. Oecol. Plant. 1980, 1, 245-252.

67. Maseyk, K.S.; Lin, T.; Rotenberg, E.; Grünzweig, J.M.; Schwartz, A.; Yakir, D. Physiology-phenology interactions in a productive semi-arid pine forest. New Phytol. 2008, 178, 603-616. [CrossRef] [PubMed]

68. Klein, T.; Hoch, G.; Yakir, D.; Körner, C. Drought stress, growth and nonstructural carbohydrate dynamics of pine trees in a semi-arid forest. Tree Physiol. 2014, 34, 981-992. [CrossRef]

69. Touchan, R.; Kherchouche, D.; Oudjehih, B.; Touchan, H.; Slimani, S.; Meko, D.M. Dendroclimatology and wheat production in Algeria. J. Arid Environ. 2016, 124, 102-110. [CrossRef]

70. Touchan, R.; Shishov, V.V.; Tychkov, I.I.; Sivrikaya, F.; Attieh, J.; Ketmen, M.; Stephan, J.; Mitsopoulos, I.; Christou, A.; Meko, D.M. Elevation-layered dendroclimatic signal in eastern Mediterranean tree rings. Environ. Res. Lett. 2016, 11, 044020. [CrossRef]

71. Rathgeber, C.; Nicault, A.; Guiot, J.; Keller, T.; Guibal, F.; Roche, P. Simulated responses of Pinus halepensis forest productivity to climatic change and $\mathrm{CO}_{2}$ increase using a statistical model. Glob. Planet. Chang. 2000, 26, 405-421. [CrossRef]

72. Sabaté, S.; Gracia, C.A.; Sánchez, A. Likely effects of climate change on growth of Quercus ilex, Pinus halepensis, Pinus pinaster, Pinus sylvestris and Fagus sylvatica forests in the Mediterranean region. For. Ecol. Manag. 2002, 162, 23-37. [CrossRef]

73. Camarero, J.J.; Gazol, A.; Tardif, J.C.; Conciatori, F. Attributing forest responses to global-change drivers: Limited evidence of a $\mathrm{CO}_{2}$-fertilization effect in Iberian pine growth. J. Biogeogr. 2015, 42, 2220-2233. [CrossRef]

74. Shestakova, T.A.; Camarero, J.J.; Ferrio, J.P.; Knorre, A.A.; Gutiérrez, E.; Voltas, J. Increasing drought effects on five European pines modulate $\Delta^{13} \mathrm{C}$-growth coupling along a Mediterranean altitudinal gradient. Funct. Ecol. 2017, 31, 1359-1370. [CrossRef]

75. Vennetier, M.; Vila, B.; Liang, E.Y.; Guibal, F.; Thabeet, A.; Gadbin-Henry, C. Impact of climate change on pine forest productivity and on the shift of a bioclimatic limit in a Mediterranean area. Options Méditerranéenne Séries A 2007, 75, 189-197.

76. Hevia, A.; Campelo, F.; Chambel, R.; Vieira, J.; Alía, R.; Majada, J.; Sánchez-Salguero, R. Which matters more for wood traits in Pinus halepensis Mill., provenance or climate? Ann. For. Sci. 2020. [CrossRef]

77. Alfaro Sánchez, R.; Camarero, J.J.; López-Serrano, F.R.; Sánchez Salguero, R.; Moya, D.; de las Heras, J. Positive coupling between growth and reproduction in young post-fire Aleppo pines depends on climate and site conditions. Int. J. Wildland Fire 2015, 24, 507-517. [CrossRef]

78. Preisler, Y.; Tatarinov, F.; Grünzweig, J.M.; Bert, D.; Ogée, J.; Wingate, L.; Rotenberg, E.; Rohatyn, S.; Her, N.; Moshe, I.; et al. Mortality versus survival in drought-affected Aleppo pine forest depends on the extent of rock cover and soil stoniness. Funct. Ecol. 2019, 33, 901-912. [CrossRef]

79. Borghetti, M.; Cinnirella, S.; Magnani, F.; Saracino, A. Impact of long-term drought on xylem embolism and growth in Pinus halepensis Mill. Trees 1998, 12, 187-195. [CrossRef] 
80. Oliveras, I.; Martínez-Vilalta, J.; Jimenez-Ortiz, T.; Lledó, M.J.; Escarré, A.; Piñol, J. Hydraulic properties of Pinus halepensis, Pinus pinea and Tetraclinis articulata in a dune ecosystem of Eastern Spain. Plant Ecol. 2003, 169, 131-141. [CrossRef]

81. Girard, F.; Vennetier, M.; Guibal, F.; Corona, C.; Ouarmim, S.; Herrero, A. Pinus halepensis Mill. crown development and fruiting declined with repeated drought in Mediterranean France. Eur. J. Forest. Res. 2012, 131, 919-931. [CrossRef]

82. Sarris, D.; Christodoulakis, D.; Körner, C. Recent decline in precipitation and tree growth in the eastern Mediterranean. Glob. Chang. Biol. 2007, 13, 1187-1200. [CrossRef]

83. Sánchez-Salguero, R.; Navarro-Cerillo, R.M.; Camarero, J.J.; Fernández-Cancio, A. Selective drought-induced decline of pine species in southeastern Spain. Clim. Chang. 2012, 113,767-785.

84. Camarero, J.J.; Gazol, A.; Sangüesa-Barreda, G.; Oliva, J.; Vicente-Serrano, S.M. To die or not to die: Early-warning signals of dieback in response to a severe drought. J. Ecol. 2015, 103, 44-57. [CrossRef]

85. De la Serrana, R.G.; Vilagrosa, A.; Alloza, J.A. Pine mortality in southeast Spain after an extreme dry and warm year: Interactions among drought stress, carbohydrates and bark beetle attack. Trees 2015, 29, 1791-1804. [CrossRef]

86. De Luis, M.; Novak, K.; Čufar, K.; Raventós, J. Size mediated climate-growth relationships in Pinus halepensis and Pinus pinea. Trees 2009, 23, 1065-1073. [CrossRef]

87. Dorman, M.; Perevolotsky, A.; Sarris, D.; Svoray, T. The effect of rainfall and competition intensity on forest response to drought: Lessons learned from a dry extreme. Oecologia 2015, 177, 1025-1038. [CrossRef] [PubMed]

(C) 2020 by the authors. Licensee MDPI, Basel, Switzerland. This article is an open access article distributed under the terms and conditions of the Creative Commons Attribution (CC BY) license (http://creativecommons.org/licenses/by/4.0/). 